\title{
CEZA MUHAKEMESİ KANUNUNDA UZLAŞTIRMA
}

\author{
Dr. Mustafa ÖZBEK
}

\section{Giriş}

Ceza Muhakemesi Hukukunda, mağdurların haklarının korunması ve suç faillerinin topluma kazandırılması amacıyla, mağdur-fail uzlaştırması (victim-offender reconciliation) hızla gelişmiştir. Uzlaştırma (arabuluculuk), geleneksel ceza muhakemesini tamamlayan, esnek ve sorun çözücü bir seçenektir. Belirli suçlarda uzlaştırma programları, Kuzey Amerika'da ve Avrupa'nın birçok ülkesinde oluşturulmuştur' ${ }^{1}$ Avusturya, Fransa ${ }^{2}$,

* Yrd. Doç. Başkent Üniversitesi Hukuk Fakültesi Öğretim Üyesi.

${ }^{1}$ Henry Brown, Arthur Marriott, ADR Principles And Practice, London 1999, s. 294; Gwen Robinson, Victim-Offender Mediation: Limitations and Potential, Oxford 1996, s. 3; John Harding, Reconciling Mediation with Criminal Justice (Mediation and Criminal Justice: Victims, Offenders and Community, London 1989, s. 27-43), s. 27; Cumhur Şahin, Ceza Muhakemesinde Uzlaşma (SÜHFD 1998/1-2, s. 221-297), s. 223; Mustafa Özbek, Çă̆daş Ceza Adaleti Sistemlerinde Alternatif Çözüm Arayışları ve Arabuluculuk Uygulaması (Ceza Muhakemesi Hukukunda Uzlaşma, İstanbul 2005, s. 85-157), s. 95; Seydi Kaymaz, Hasan Tahsin Gökcan, Türk Ceza ve Ceza Muhakemesi Hukukunda Uzlaşma ve Önödeme, Ankara 2005 , s. $38 \mathrm{vd}$.

2 Örneğin, "Fransız hukukunda kişiler arasındaki uyuşmazlıklar, savcılığın görevlendirdiği arabulucunun girişimiyle çözülmeye çalışılmaktadır. Fransız Ceza Usul Kanunu'nun 41. maddesine göre (Le Code de procédure pénale), kamu davası açılmasına karar verilmesinden önce, Cumhuriyet savcısı, tarafların rıza göstermesi hâlinde arabuluculuğa (La médiaiton) başvurabilir. Bunun için, arabuluculuk sayesinde verilen zarar tazmin edilebilmeli, suçun ortaya çıkardığı huzursuzluğa son verilebilmeli veya failin yeniden topluma kazandırılması mümkün olmalıdır. Hafif cezayı gerektiren basit suçlarda başvurulan arabuluculukta tarafların özür dilemesi, verilen zararın tazmin edilmesi, sanığa savcı tarafindan adli tevbihte bulunulması, sanığın bazı kamu hizmetlerinde çalıştırılması veya düşük bir para cezasının ödenmesi suretiyle uyuşmazlık arabuluculukla çözülebilmektedir. Ceza arabuluculuğunun mutlaka mahkemece yürütülmesi şart olmayıp polis, savcılık teşkilatı, suçlunun meşruten tahliye edildiği dönemde suçluyu gözlemleyen kuruluş veya bağımsız bir topluluk temelli kuruluş tarafindan yürütülmesi de mümkündür. Arabuluculuğun başarılı olması hâlinde mağdurun zararı tazmin edilmiş olacağından, savcı takipsizlik kararı verebilecek ve böylece 
Almanya, Norveç ve İspanya gibi Avrupa ülkelerindeki gelişmeler neticesinde, Avrupa Konseyi Bakanlar Komitesi de özel bir çalışma başlatmış ve 15 Eylül 1999'da, R (99) 19 sayılı “Ceza Uyuşmazlıklarında Uzlaştırma" konulu tavsiye kararını kabul etmiştir ${ }^{3}$.

Avrupa Konseyi Bakanlar Komitesinin tavsiye kararında, ceza uyuşmazlıklarında uzlaştırmaya yönelik ilkelere yer verilmiştir. Bu tavsiye kararına göre mağdur-fail uzlaştırması, mağdur ve failin, özgür iradeleriyle kabul etmeleri hâlinde, tarafsız bir üçüncü kişinin yardımıyla, suçtan ortaya çıkan sorunların çözümüne aktif olarak katıldıkları bir süreçtir ${ }^{4}$. Mağdur-fail uzlaştırmasında taraflar, mağdurun zararının giderilmesi hususunda bir anlaşmaya varmaya çalışırlar. Mağdurun zararının giderilmesi, mağdura bir miktar tazminat ödenmesi şeklinde olabileceği gibi, mağdur veya toplum için belirli bir kamu hizmetinde bulunulması şeklinde de olabilir ${ }^{5}$.

\section{Genel Olarak Mağdur-Fail Uzlaştırması}

Türk Ceza Muhakemesi Hukukunda uzlaştırmayı incelemeye geçmeden önce, genel olarak mukayeseli hukukta uygulanan mağdur-fail uzlaştırmasını incelemek gerekir.

Mağdur-fail uzlaştırması, gerek Anglo-Amerikan hukukunda, gerek kıta Avrupası hukukunda uzun ve başarılı bir geçmişe sahiptir. Mağdur-fail uzlaştırmasının, 1974 yılında Kanada'da (Ontario, Elmira), iki çocuğa kaşı açılan bir ceza davasıyla doğduğu kabul edilir. Bu davada, yirmi iki defa mala zarar verme suçu işleyen ve daha önce hiçbir ceza almamış olan çocuklar suçlarını kabul etmişlerdir. Açılan davada, Mennonite kontrol memuru (probation/parole officer) ve Mennonite gönüllü koordinatörü, davaya bakan hâkime, çocuklarla mağdurların görüştürülerek terapiye dayalı bir yol izlenmesini önermişlerdir. Hâkim, başlangıçta bu teklife kuşkuyla yaklaşmış, fakat daha sonra çocukların, mağdurlara verdikleri zararı öğrenmeleri için onlarla görüşmelerine ve kendisine bilgi vermelerine karar vermiştir. Çocukların her iki mağdurla da görüşmesinin ardından, mağdurların sigorta kapsamı dışında kalan zararları belirlenmiştir. Bu husus

mahkemelerin iş yükü hafifleyecektir. Ayrıca, arabuluculuk sayesinde mağdur, uzun ve yıpratıcı bir dava sürecine katlanmak zorunda olmaksızın zararının tazminini daha çabuk sağlayabilecektir (Jean Larguier, Procédure penale, Paris 1995, s. 64; Fahrettin Hekimoğlu, Fransa'da Hukukî Danışmanlık ve Arabulculuk Uygulaması, ABD 2002/2, s. 33-38, s. 38).

3 Committee of Experts on Mediation in Penal Matters, Mediation in Penal Matters, Recommendation N R (99) 19 adopted by the Committee of Ministers of The Council of Europe on 15 September 1999 and explanatory memorandum; Mustafa Özbek, Avrupa Konseyi Bakanlar Komitesinin "Ceza Uyuşmazlıklarında Arabuluculuk” Konulu Tavsiye Kararl (DEÜHFD 2005/1, s. 127-166).

${ }^{4}$ Committee of Experts on Mediation in Penal Matters s. 5.

${ }^{5}$ Brown, Marriott s. 294; Hamide Zafer, Ceza Muhakemesi Hukukunda Özelleşme Eğilimi: Uzlaşma (Prof. Dr. Ergun Önen'e Armağan, İstanbul 2003, s. 727-750), s. 728. 
hâkime bildirildiğinde hâkim, çocukların bu zararı tamamen tazmin etmelerine karar vermiştir. Bu uygulama daha sonra "mağdur-fail uzlaştırma programı" (victim-offender reconciliaiton program, VORP) olarak adlandırılmıştır ${ }^{6}$.

Birleșik Devletler'de ilk mağdur-fail uzlaştırması programı, 1978 yılında, Indiana, Elkhart'da, Denetimli Serbestlik Bölümünün bünyesinde başlamıştır. Bu program kısa sürede, toplum kökenli ve kamusal olarak finanse edilen bir program hâline dönüştürülmüştür. Mennonite Merkezî Komitesinden Howard Zehr ile Birleşik Devletler Ceza Adaleti Bürosu, Birleşik Devletler'de mağdur-fail uzlaştırma programının temel kurucusu ve geliştiricisi olarak tanınır. Program, Elkhart'tan sonra Birleşik Devletler'in her yerine yayılmıştır. Bugün Birleşik Devletler'de uygulanan yaklaşı 100 adet program vardır. Ayrıca, Kanada'da 26 program faaliyet göstermekte, Avustralya, Yeni Zelanda, İngiltere, Almanya ve diğer Avrupa Ülkelerinde ${ }^{8}$ de çok sayıda program bulunmaktadır.

Ceza uyuşmazlıklarında uzlaştırmanın ilk örneklerinde, şikâyet yapılması üzerine uzlaştırmaya başvurulmuştur. Bunun yanında, dava açıldıktan sonra da uzlaştırma mümkündür. Bu uygulama esas itibariyle, geleneksel olarak uzlaştırmanın kullanılmadı̆̆ "plea bargain" sürecini ifade etmiştir. Sanığın bir ceza soruşturmasında, daha hafif bir ceza alma beklentisiyle, aleyhindeki ithamı kabul ettiği bu usulde ${ }^{9}$, savc1 ve müdafi bizzat müzakere eder ve genellikle bir uzlaştırıcıya ihtiyaç duyulmaz. Bununla beraber, birçok olayda tarafsız bir uzlaştırıcı, tatminkâr bir çözüm bulunmasında taraflara yardım edebilir.

Dava açılmasında sonra, failin denetimli serbestlik veya zararı giderme sürecinin bir parçası olarak uzlaştırmaya başvurulmaktadır. Mağdur-fail uzlaştırmasında, failin mağdura vermiş olduğu zararı giderim şekli üzerinde müzakere edilir. Birleșik Devletler'de yapılan çalıșmalar, hem mağdurların, hem faillerin uzlaştırmadan yararlandıklarını; katılımcıların uzlaştırma sürecinden tatmin olduklarını ve uzlaştırma sonunda ceza adaleti sistemine

${ }^{6}$ Dean E. Peachey, The Kitchener Experiment (Mediation and Criminal Justice: Victims, Offenders and Community, London 1989, s. 14-26), s. 15; Gwen Robinson, Victim-Offender Mediation: Limitations and Potential, Oxford 1996, s. 14; Kimberlee K. Kovach, Mediation, Principles and Practice, St. Paul 2004, s. 483.

${ }^{7}$ Almanya'da uygulanan mağdur-fail uzlaştırma programları hakkında bilgi için bkz. Dieter Rössner, Mediation as a Basic Element of Crime Control: Theoretical and Empirical Comments (Buffalo Criminal Law Review 1999, Vol. 3, s. 211-233); Detlev Frehsee, Restitution and Offender-Victim Arrangement in German Criminal Law: Development and Theoretical Implications (Buffalo Criminal Law Review 1999, Vol. 3, s. 235-259).

${ }^{8}$ Avrupa ülkelerinde uzlaştırmaya ilişkin düzenlemeler için bkz. Kaymaz, Gökcan s. 38-46; Zafer s. 732

${ }^{9}$ David W. Neubauer, America's Courts and the Criminal Justice System, New York 1999, s. 309. 
daha olumlu baktıklarını göstermiştir ${ }^{10}$. Ceza adaleti sistemi onarıcı adaletle (restorative justice) ilgili konular üzerinde yoğunlaştıkça ${ }^{11}$ mağdur-fail uzlaştırması gelişmektedir ${ }^{12}$.

Mağdur-fail uzlaştırması, özel hukuk uzlaştırmasından belirli yönleriyle ayrılır. Birinci olarak, mağdur-fail uzlaştırmasında sonuca bağlanamamış sorunların görüşülmesi üzerinde değil, mağdurun zararının giderilmesi üzerinde durulur. İkinci olarak, uzlaştırma sürecine katılım için özel seçim kıstasları belirlenmiştir. Örneğin bazı mağdur-fail uzlaştırma programlarında, sadece mala karşı işlenen suçlara bakılır ve failin ikiden fazla mahkûmiyetinin olmaması gerekir. Bununla beraber son zamanlarda, cinsel saldırı ve kasten öldürme suçları gibi daha ağır suçlarda da uzlaştırmadan yararlanılmaya başlanmıştır. Ceza evlerinde ortaya çıkan uyuşmazlıklar da uzlaştırmaya havale edilmektedir. Birleşik Devletler'de bazı eyalet hapishaneleri, hükümlülerin şikâyetlerini incelemek üzere uzlaştırma programları kurmuştur ${ }^{13}$.

Birleșik Devletler'de eyaletlerin yasal düzenlemeleriyle, çeşitli suçlarda ve özellikle çocuklar tarafından işlenen suçlarda, kâr amacı gütmeyen uzlaştırma programları oluşturulmuştur ${ }^{14}$.

Mağdur-fail uzlaştırma programlarının amacı, faillerin kendi fiillerinin sonuçlarını görerek bizzat anlamaları için, suçun faili ile mağduru arasında doğrudan iletişim kurulmasıdır. Bu tür toplantılar mağdurların, geleneksel yarg1 sisteminin üstesinden gelmekte zorlandığ 1 zayıflık duygusunu yenmelerine yardımc1 olur ${ }^{15}$. Adalet sistemini mücadeleci ve cezalandırıc1 bir süreçten, işbirliğine dayalı bir sürece dönüştürmekte, eğitimli ve gönüllü uzlaştırıcılar, taraflara anlaşmaya varmaları için yardım edebilir. Mağdur-fail uzlaştırması, mağdurların ve faillerin, gerçek anlamda sorumluluklarını bilmeleri ve yeniden uzlaşmaları için neye ihtiyaç duyduklarını anlamalarını sağlar.

\footnotetext{
${ }^{10}$ Kovach s. 483.

11 Onarıcı adalet konusunda bilgi için bkz. James Coben, Penelope Harley, Intentional Conversations About Restorative Justice, Mediation and the Practice of Law (Hamline Journal of Public Law and Policy 2004, Vol. 25, s. 235-334).

${ }^{12}$ Katherine L. Joseph, Victim-Offender Mediation: What Social and Political Factors Will Affect Its Development? (Ohio State Journal on Dispute Resolution 1996, Vol. 11, s. 207225), s. 216. Ellen A. Waldman, Healing Hearts or Righting Wrongs?: A Meditation on the Goals of "Restorative Justice" (Hamline Journal of Public Law and Policy 2004, Vol. 25, s. 355-373), s. 359.

${ }^{13}$ Kovach s. 484; Mark S. Umbreit, Mediating Criminal Conflict (Handbook of Alternative Dispute Resolution, Austin 1990, s. 227-238), s. 236.

${ }^{14}$ Neubauer s. 479.

15 Susan C. Taylor, Victim-Offender Reconciliation Program-A New Paradigm Toward Justice (The University of Memphis Law Review 1996, Vol. 26, s. 1187-1195), s. 1188.
} 
Mağdur-fail uzlaştırmasında, hem faillerin, hem mağdurların topluma yeniden kazandırılarak, uğradıkları zararların giderildiğine inanılır. $\mathrm{Bu}$ programa katılım her iki taraf için de tamamen gönüllüdür ve programa gizlilik hâkimdir.

Mağdur-fail uzlaştırması, mağdurlar ve faillere birçok yarar sağlar. Öncelikle, uzlaştırma sayesinde, mağdurlar çok nadir bulabilecekleri bir firsat olan faille karşı karşıya gelme imkânına sahip olur. Eğitimli ve gönüllü bir uzlaştırıcının yönetiminde yapılan toplantıda mağdur, acısını, zararını ve duygularını faile açıklar. Uzlaştırma müzakereleri, mağdurun sorularının cevaplanmasına ve böylece korkularının azalmasına olanak tanır. Mağdurlar, ceza muhakemesi sürecinde seslerini duyurabildiklerini düşünür ve mağdurlara failin hayatını olumlu yönde etkileme şansı verilir.

Failler, uzlaştırma sürecinde işledikleri suçu bizzat değerlendirerek sorumluluklarının farkına varırlar. $\mathrm{Bu}$ sayede, faillerin işledikleri suçun neticelerini anlamalarına ve pişmanlıklarını dile getirerek özür dilemelerine imkân tanınır. Bundan sonra fail, mağdura ve topluma verdiği zararı giderebilir.

Mağdur-fail uzlaştırma programları toplumun da yararınadır. Uzlaştırma sayesinde, ağır olmayan suçlarda faillere hapis cezası vermek yerine, yararlı bir alternatif tedbire başvurulur. Böylece hem yargılama, hem ceza evi masraflarından büyük ölçüde tasarruf edilir. Bunlardan da önemlisi, toplumdaki uzlaştırma programları, anlaşmazlık çözümünde dostane yöntemlerin öğrenilmesini sağlar. Uzlaştırma sürecinde yer alan kişiler (mağdur, fail veya uzlaştırıc1), uzlaştırmada edindikleri tecrübeleri başka hiçbir yerde öğrenemezler ${ }^{16}$.

Mağdur-fail uzlaştırma programları başlıca şu alanlarda uygulanmaktadır:

1) Ceza ve çocuk mahkemelerinden gönderilen davaların görüldüğ̈̈ ve davanın sonucu hakkında mahkemelere rapor verilen mahallî uzlaştırma merkezlerinde,

2) Toplumu ceza adalet sistemi hakkında eğiten mahallî toplum kuruluşlarında,

3) Toplumda dostane uyuşmazlık çözümünü yaygınlaştırmayı amaçlayan diğer uzlaştırma programlarında.

Mağdur-fail uzlaştırmasının işleyişi şu şekildedir:

1) Ceza davası (örneğin hırsılılıtan dolayı açılan) mahkeme tarafından mağdur-fail uzlaştırmasına gönderilir.

\footnotetext{
16 Taylor s. 1189.
} 
2) Dava uzlaştırmaya uygunluk açısından incelenir (fail suçtan dolayı sorumluluğunu kabul etmiş olmalıdır).

3) Uzlaştırıcı, fail ve mağdurla kişisel olarak görüşür.

4) Uzlaştırma süreci başlar. Mağdur ve fail, duygu ve düşüncelerini, uzlaştıııcının yardımıyla açıklar ve giderim şekli üzerinde anlaşmaya varılır.

5) Uzlaştırmanın sonucu ve başarısı hakkında bilgi ve tavsiyeler içeren bir rapor hazırlanarak dava dosyası mahkemeye geri gönderilir.

6) Zararın, üzerinde anlaşmaya varıldığı şekilde giderilip giderilmediği izlenir.

7) Zarar anlaşmaya uygun olarak giderildiğinde, davanın düşmesine karar verilir ve raporlar dava dosyasına koyulur ${ }^{17}$.

Uzlaştırma süreci kişilerin, etkin iletişim ve sorun çözme hünerleri kullanma yoluyla, anlaşmazlıkları korkuya, baskıya ve cezalandırmaya dayalı olmayan bir ortamda çözmelerine imkân tanır. Çocukların taraf olduğu anlaşmazlıklarda uzlaştırmaya başvurulması çeşitli nedenlerden dolayı büyük yarar taşır. Öncelikle çocuk adalet sistemi, çocuklarla ilgili sorunların çözülmesinde her zaman uygun bir süreç olmaz. Bunun yanında uzlaştırma süreci, çocuklar için başlı başına önemli bir eğitim sayılır. Anlaşmazlıkların ifade edilmesi ve çözülmesinde yeni yöntemlerin oluşturulması, sosyal ve kişiler arası hünerlerin gelişmesine yardım eder.

Uzlaştırma, mukayeseli hukukta adalet sisteminde büyük ilgi görmektedir. Mağdur-fail uzlaştırma programları, çok sayıdaki alternatif uyuşmazlık çözüm yollarından sadece biridir. Bu tür uzlaştırma programları sayesinde, ceza adaleti sisteminde alternatif tedbirlerin önemi daha açık hâle gelmiştir.

\section{Türk Ceza Hukukunda Uzlaștırmayı Düzenleyen Hükümler}

Ceza Hukukumuzda, 5237 sayılı Türk Ceza Kanunu ${ }^{18}$ ve 5271 sayılı Ceza Muhakemesi Kanunu ${ }^{19}$ ile uzlaştırmaya başvurulması olanaklı kılınmıştır.

\section{A) Terminoloji Sorunu}

Uzlaştırma kurumu, gerek Türk Ceza Kanununda, gerek Ceza Muhakemesi Kanununda "uzlaşma" adıyla düzenlenmiştir. Uzlaşma,

\footnotetext{
17 Taylor s. 1190.

${ }^{18}$ RG 12.10.2004, Sa. 25611.

${ }^{19}$ RG 17.12.2004, Sa. 25673.
} 
tarafların, herhangi bir üçüncü kişinin yardımı olmadan, aralarındaki uyuşmazlığa bir çözüm bulabilmek ve bir anlaşma zemini oluşturabilmek amacıyla yaptıkları görüşmelere verilen isimdir. $\mathrm{Bu}$ anlamda uzlaşma, alternatif uyuşmazlık çözüm yollarından "müzakere" ile eş anlamlıdır ve yabanc1 literatürde, "negotiation", "settlement" veya "compromise" kelimeleriyle ifade edilmektedir ${ }^{20}$. Ceza Muhakemesi Kanununda düzenlenen uyuşmazlık çözüm yolunda, mağdur-fail arasındaki uyuşmazlık çözüm sürecine tarafsız bir üçüncü kişinin (neutral third party), katılımı söz konusudur. $\mathrm{Bu}$ usulde uyuşmazlığın tarafları, tarafsız bir uzlaştırıcının (arabulucunun) yönetiminde bir araya gelirler. Tarafları bağlayıcı bir karar verme yetkisi olmayan uzlaştırıcı (conciliator, mediator), belirli usuller, yöntemler ve müzakere hünerlerini kullanarak, tarafların uyuşmazlığ 1 çözmelerine yardımcı olur. Uzlaştırma genellikle arabuluculukla aynı anlamda kullanılır ${ }^{21}$ ve yabancı literatürde "conciliation ve "mediation" kelimeleriyle ifade edilir22. Ceza Muhakemesi Kanununda "uzlaşma" ile ifade edilmek istenen usul aslında "uzlaştırma"dır. Bu nedenle, bu çalışmada "uzlaştırma" kelimesi kullanılacaktır. Yapılacak bir kanun değişikliğiyle, kanunda da uzlaştırma kelimesinin tercih edilmesi daha doğru olur.

\section{B) Türk Ceza Kanununda Uzlaştırmanın Düzenlenme Amacı}

Uzlaştırma, Türk Ceza Kanununun 73. maddesinde düzenlenmiştir. Uzlaştırma kurumunun amacı, hükûmet gerekçesinde, şöyle açıklanmıştır ${ }^{23}$ :

"Maddenin (2) numaralı fikrası ile düzenlenen uzlaşma, esasında Ceza Muhakemeleri Usulü Kanununda yer alması gereken yeni bir kurumdur; ancak Ceza Kanununda esas hükmün yer alması ve Usul Kanununda uygulamanın düzenlenmesi zorunludur. Bu nedenle maddenin (2) numaralı fikrasında kuruma yer verilmiştir.

Maddenin (2) numaralı fikrasiyla ceza adalet sisteminde reform sayılabilecek bir kurum olarak 'Uzlaşma' kurumu tanımlanmıştır.

Çağımızda suç mağdurlarına karşı ceza adalet sisteminde, mağdurların yararları yönünde yeni bir duyarlılığın ortaya çıktığı görülmektedir. Ülkemizde bugüne kadar mağdurlara karşı gösterilen özel dikkat sadece bazı adam öldürme, terör ve örgütlü suçlar bakımından söz konusu oluyordu. Bazı özel kanunlarda (örneğin 3/11/19802 tarih ve 2330 sayılı Nakdî Tazminat ve Aylık Bağlanması Hakkında Kanunda olduğu gibi) suç mağdurlarına veya ailelerine Devletin tazminat ödemesi öngörülmektedir.

${ }^{20}$ Brown, Marriott s. 655 .

${ }^{21}$ Mustafa Özbek, Alternatif Uyuşmazlık Çözümü, Ankara 2004, s. 103-106.

${ }^{22}$ Brown, Marriott s. 654.

${ }^{23}$ T.C. Başbakanlık Kanunlar ve Kararlar Genel Müdürlüğü, Türk Ceza Kanunu Tasarısı, 12.5.2003, Ankara, s. 44-45. 
Bununla berber çağdaş ceza kanunlarında diğer bir kısım suçlar bakımından da koruma ilkeleri meydana çıkmaya başlamıştır. XXI. Yüzyıl adalet sistemi mağdurun tatmin edilmesini de ön plâna çıkarmış bulunmaktadır. Bugün anlaşılmıştır ki, suça karşı salt ceza yaptırımları yeterli değildir. Zararın giderilmesi ve onarım, hiç şüphesiz, adaletin temel amacını oluşturmaktadır. Ancak bu tek görünüm değildir.

Uzlaşmanın hedefi suçun işlenmesinden sonra fail ve mağdur arasında meydana gelen çekişmeyi, bir arabulucunun girişimini sağlayarak çözmek ve adaleti sağlamaktır. Failin neden olduğu zararın giderilmesi, fail-mağdur arasındaki barış, uzlaşmanın asıl unsurunu oluşturur. Fail-mağdur arasında uzlaşma dışında da, tazminatın sağlanması olanaklıdır. Ancak uzlaşma kurumunda, zararın giderilmesi ve onarım yanında ayrıca bir moral unsur da vardır. $\mathrm{Bu}$ nedenle fail-mağdur arasındaki uzlaşma suçun faili bakımından cezanın 'özel önleme' fonksiyonuna yardım ettiği gibi mağdurun ve genel olarak kamunun da yararlarının korunmasını sağlar. Fail, uzlaşma ile, işlediği suçun sorumluluğunu kabul edip üstlenerek ve sonuçlarını da gidererek toplumla yeniden bütünleşme olanağını elde etmiş olur. Böylece failin ceza sorumluluğunu tespit ve zararın giderilmesi için gereken yapılmış bulunacağından, mağdur bakımından da adalet yerine getirilmiş olur. Fail-mağdur arasındaki uzlaşma, bundan başka, kamuda da, fille ihlâl edilmiş olan hukuk kurallarının geçerliliğini vurgulamış ve dolayısıyla kamusal barışın yeniden kurulmasına hizmet etmiş olur.

Tasarının kabul ettiği sisteme göre, uzlaşma aşağıdaki esaslara göre gerçekleştirilmektedir.

a) Uzlaşma sadece soruşturulması ve kovuşturulması şikâyete bağlı suçlar için geçerlidir. Böylece sadece küçük ihtilafları içeren suçlar bakımından (hakaret, sövme, tehdit, basit nitelikli eylem gibi) bu yola gidilebilecektir. $\mathrm{Bu}$ ayırım ile, hukukumuzda yargı organlarının daha ağır suçlara ayırabilecekleri zaman alanı genişletilmekte ve küçük suçlarda tamamen yenileştirilmiş bir yaptırım sistemi geliştirilmektedir. Tasarı, ceza adaletinde onarıcı bir sistemi böylece organik olarak gerçekleştirmektedir.

b) Failin suçu ve sorumluluğunu kabullenmesi gerekir. Fail fiilini inkâr etmemelidir. Fail, kendisine isnat olunan suçları işlemediğini öne sürecek olursa o zaman ceza yargılama kuralları uygulanarak durumun aydınlatılması gerekir ve uzlaşma kurumu işletilmez.

c) Fail suçtan doğan zararın tümünü veya büyük bir kısmını ödemeli ve gidermelidir. Zararın giderilmesi failden dikkati çekecek surette büyük miktarda edimlerin yerine getirilmesini veya kişisel bir takım özverilerde bulunmasını gerektirdiği durumlarda, failin bütünüyle veya geniş bir kısmı itibariyle mağdurun zararlarını tazmin etmeye çalışması aranır. 
d) Fail ve mağdur özgür iradeleriyle uzlaşmalıdırlar. Uzlaşma yoluna gidecek olan fail ve mağdur, bu yolu, gönüllü olarak kabul etmelidirler. Fiil, doğru olarak ve her iki tarafça kabul edilebilecek şekilde saptanmalı ve bir çözüm yolu bulunmalıdır.

e) Fail ve mağdurun uzlaştıkları Cumhuriyet savcısı veya hâkim tarafından saptanmalıdır. Suçtan doğan zararın onarımına veya zararın giderilmesine ilişkin taraf iradeleri ceza yargılama hukuku kurallarına göre saptanacaktır.

f) Soruşturma evresinde Cumhuriyet savcısı fail-mağdur arasındaki uzlaşmayı saptadığında kamu davası açılmayacaktır. Bu tespit kovușturma evresinde hâkim tarafindan yapıldığında fail hakkında mahkûmiyet hükmü verilmeyecektir. Bunun anlamı şudur ki, failin suçun zararlı sonuçlarını gidermek üzere yapacağı hareketler, ceza kovuşturmasının başlamaması veya son verilmesi ile sonuçlanacaktır."

\section{C) Uzlaştırmaya Konu Olabilecek Suçlar}

Uzlaştırmaya başvurulabilmesi için öncelikle, kanunun uzlaştırma yapılabilmesi olanağını verdiği bir suç mevcut olmalıdır (CMK m. 253,1). Hangi suçlarda uzlaştırmaya başvurulabileceği, Türk Ceza Kanununun 73. maddesinde belirtilmiştir. $\mathrm{Bu}$ maddeye göre, soruşturulması ve kovuşturulması şikâyete bağlı bulunan suçlarda uzlaştırmaya başvurulabilir. 5237 sayılı Türk Ceza Kanununda, soruşturulması ve kovuşturulması şikâyete bağlı bulunan suçların kapsamı genişletilmiştir ${ }^{24}$. Buna göre; kasten yaralama suçunda, yaralama fiilinin kişi üzerindeki etkisinin basit bir tıbbî müdahaleyle giderilebilecek ölçüde hafif olması hâlinde (TCK m. 86, 2), bilinçli taksir hâli dışında taksirle yaralama (TCK m. 89), cinsel saldırı (TCK m. 102,1,2), reşit olmayanla cinsel ilişki (TCK m. 104,1), cinsel taciz ${ }^{25}$

24 Türk Ceza Kanununda, soruşturulması ve kovuşturulması şikâyete bağlı bulunan suçların sıralaması için bkz. Zekeriya Yılmaz, Ülkemizde Ceza Kanunu Hazırlık Çalışmaları ve Yeni Türk Ceza Kanunu Hakkında Değerlendirme (TNBHD 2005/125, s. 28-41), s. 39

${ }^{25}$ Ceza Muhakemesi Hukukunda, cinsel dokunulmazlığa karşı suçlarda uzlaştırma yolunun açılması önemli bir yeniliktir. İlk bakışta, bu tür suçlarda uzlaştırma olanağının tanınmasının ahlâk kurallarıyla bağdaşmayacağı, mağdurun onurunu zedeleyebileceği ve hatta bazı hâllerde mağdurun aleyhine olabileceği düşünülse de, aslında uzlaştırma süreci, özellikleri itibariyle mağdura birçok yarar sağlayacaktır. Her şeyden önce, bu tür suçlarda travmatik bir tecrübe yaşayan mağdur, yargılama sürecinde çeşitli vesilelerle (örneğin beden muayenesi) tekrar bu olayları hatırladığı için psikolojik olarak zarar görmektedir. Bu tür işlemlerden kurtulan mağdur, uzlaştırma sürecinin gizli olması sayesinde, aleniyet ilkesinin hâkim olduğu dava sürecinde maruz kaldığı utanma duyusuna katlanmayacaktır. Ayrıca, uzlaştırmaya başvurulmasının zorunlu olmadığı, mağdurun istediği takdirde bu yola gideceği de unutulmamalıdır. Cinsel dokunulmazlığa karşı suçlarda uzlaştırmanın eleştirisi için bkz. Ayşe Nuhoğlu, Uzlaşma Bakımından Şikayete Bağlı Suçlar (Ceza Muhakemesi Hukukunda Uzlaşma, İstanbul 2005, s. 281-284) s. 284. 
(TCK m. 105,1), tehdit (TCK m. 106,1), konut dokunulmazlığının ihlâli (TCK m. 116,1), iş ve çalışma hürriyetinin ihlâli (TCK m. 117,1), kişilerin huzur ve sükununu bozma (TCK m. 123), kamu görevlisine karş1 görevinden dolay1 işlenen hariç hakaret (TCK m. 125; 130; 131,1), haberleşmenin gizliliğini ihlâl (TCK m. 132), kişiler arasındaki konuşmaların dinlenmesi ve kayda alınması (TCK m. 133), özel hayatın gizliliğini ihlâl (TCK m. 134; ayrıca bkz. m. 139), paydaş veya elbirliği ile malik olunan mal üzerinde hırsızlık veya bir hukukî ilişkiye dayanan alacağı tahsil amacıyla hırsızlık (TCK m. 144,1), kullanma hırsızlığ 1 (TCK m. 146,1), mala zarar verme (TCK m. 151,1,2), güveni kötüye kullanma (TCK m. 155,1), bedelsiz senedi kullanma (TCK m. 156), bir hukukî ilişkiye dayanan alacağı tahsil amacıya işlenen dolandırıcilık (TCK m. 159,1), kaybolmuş veya hata sonucu ele geçmiş eşya üzerinde tasarruf (TCK m. 160), açığa imzanın kötüye kullanılması (TCK m. 209,1), aile hukukundan kaynaklanan yükümlülüğün ihlâli (TCK m. 233,1) ve ticarî sır, bankacılık sırrı veya müşteri sırrı niteliğindeki bilgi veya belgelerin açıklanması (TCK m. 239,1,2) suçlarında uzlaştırmaya başvurulabilir.

Küçükler tarafından işlenen suçlularda da uzlaştırmaya başvurulabilir ${ }^{26}$. Çocuk Koruma Kanununun ${ }^{27}$ 24. maddesine göre, suça sürüklenen çocuklarla ${ }^{28}$ ilgili olarak uzlaştırma, soruşturulması ve kovuşturulması şikâyete bağlı olan veya kasten işlenen ve alt sınırı iki yılı aşmayan hapis veya adlî para cezasını gerektiren ya da taksirle işlenen suçlarda uygulanır (Çocuk Koruma Kanunu m. 24,1). Suç tarihinde onbeş yaşını doldurmayan çocuklar bakımından, Kanunun birinci fikrasında öngörülen hapis cezasının alt sınırı üç yıl olarak uygulanır (Çocuk Koruma Kanunu m. 24, 1). Çocuklar tarafindan işlenen suçlarda uzlaştırmaya konu olabilecek suçlar, sadece takibi şikâyete bağlı suçlarla sınırlı tutulmamıştır. Çocukların işlediği suçlarda uzlaştırmaya başvurulması hâlinde, uzlaştırmanın işleyişine iliş̧in özel bir düzenleme bulunmamaktadır. Çocuk Koruma Kanununda hüküm bulunmayan hâllerde Ceza Muhakemesi Kanunu uygulanacağından (Çocuk Koruma Kanunu m. 42,1), uzlaştırmanın işleyişi Ceza Muhakemesi Kanununun 253 ve devamındaki maddelerine göre gerçekleştirilecektir. Çocuklar hakkında özgürlüğü kısıtlayıcı tedbirler ile hapis cezasına en son

${ }^{26}$ Küçükler tarafından işler suçlularda da mağdur-fail uzlaştırması hakkında bkz. Bruce A. Arrigo, Robert C. Schehr, Restoring Justice for Juveniles: A Critical Analysis of VictimOffender Mediation (Justice Quarterly 1998, Vol. 15, s. 629-666); Barton Poulson, Kathy Elton, Participants' Attitudes in the Utah Juvenile Victim-Offender Mediation Program (Juvenile and Family Court Journal 2002, Vol. 53, s. 37-46); Stephanie A. Beauregard, CourtConnected Juvenile Victim-Offender Mediation: An Appealing Alternative for Ohio's Juvenile Delinquents (Ohio State Journal on Dispute Resolution 1998, Vol. 13 s. 1005-1038); Debra Baker, Juvenile Mediation Innovative Dispute Resolution or Bad Faith Bargaining (Univesity of Toledo Law Review, 1996, Vol. 27, s. 897-920).

${ }^{27}$ RG. 15.07.2005, Sa. 25876.

28 Çocuk Koruma Kanununun 3. maddesinin (a) bendine göre çocuk, onsekiz yaşını doldurmamış kişiyi ifade eder. 
çare olarak başvurulması ilkesi dikkate alındığında (Çocuk Koruma Kanunu m. 4,1/i), Çocuk Koruma Kanununda çocuk suçlular için uzlaştırmaya yer verilmesi isabetli olmuştur. Ayrıca, Çocuk Haklarının Kullanılmasına İlişkin Avrupa Sözleşmesi ${ }^{29}$ (European Convention on the Exercise of Children's Rights) gibi çeșitli uluslararası belgelerde de, çocuk suçlular hakkında uzlaştırma yolunun geliştirilmesi önerilmektedir. Bununla birlikte, uzlaştırma sürecinin işleyişinde çocuklara özel düzenlemeler yapılması gerekir. Ceza muhakemesinde çocukların korunması için öngörülen güvenceler, hem davanın uzlaştırmaya havalesinde, hem uzlaştırma sürecinde uygulanmalıdır. Özellikle çocuk ve ailesinin bilgilendirilmesi suretiyle uzlaştırma sürecine katılmaları, görüş ve düşüncelerini açıklamaları, etkili ve sür'atli bir uyuşmazlık çözüm sürecinin izlenmesi uzlaştırmada da sağlanmalıdır (Çocuk Koruma Kanunu m. 4,1/d,f).

Uzlaştırma, Türk Ceza Kanununun genel hükümleri içeren Birinci Kitabında (TCK m. 1-75) düzenlenmiştir. Türk Ceza Kanununun genel hükümleri, "özel ceza kanunları ve ceza içeren kanunlardaki suçlar" hakkında da uygulanacağından (TCK m. 5), Türk Ceza Kanunu dışındaki kanunlarda yer alan takibi şikâyete bağlı suçlarda da uzlaștırmaya başvurulması mümkündür ${ }^{30}$. Örneğin, İcra ve İflâs Kanununun 331, 332, $333 \mathrm{a}, 334,336 \mathrm{a}, 337,337 \mathrm{a}, 338,339,340,341,343,344$ ve 345a maddelerinde yazlı suçlar takibi şikâyete bağlı olduğu için, bu suçlarda uzlaştırmaya başvurulabilir ${ }^{31}$. Özellikle İcra ve İflâs Kanununda yer alan suçlarda (örneğin yükümlülüklerin yerine getirilmemesi, hakikate muhalif beyanda bulunma veya ödeme şartını ihlâl suçlarında) uzlaştırmadan önemli ölçüde yaralanılabilir. İcra ve İflâs Kanununun 354. maddesine göre, Kanunun 331 ilâ 353. maddelerinde yazılı suçlardan takibi şikâyete bağlı olanlarda, mağdur şikâyetinden vazgeçerse veya borç ödenirse, ceza davası ve cezaya hükmedilmişse bütün sonuçlarıyla birlikte ceza düşmektedir. $\mathrm{Bu}$ madde, İcra ve İflâs Kanununda yer alan takibi şikâyete bağlı suçlarda, mağdurun zararının giderilmesinin amaçlandığını göstermektedir. Böylece, mağdurla fail uzlaştığı ve mağdurun zararı giderildiği takdirde, şikâyetten vazgeçilebilir (veya şikâyet geri alınabilir) ve dava ortadan kaldırılır. Bu

\footnotetext{
${ }^{29} \mathrm{Bu}$ Sözleşme için bkz. http://conventions.coe.int/Treaty/en/Treaties/Html/160.htm; Ankara Barosu, Çocuk Haklarının Kullanılmasına İlişsin Avrupa Sözleşmesi, Ankara 2001.

${ }^{30}$ Her ne kadar, 5349 sayılı Türk Ceza Kanununun Yürürlük ve Uygulama Şekli Hakkında Kanunda Değişiklik Yapılmasına Dair Kanunun (RG 18.05.2005, Sa. 25819) Geçici 1. maddesinde, "diğer kanunların, 5237 sayılı Türk Ceza Kanununun Birinci Kitabında yer alan düzenlemelere aykırı hükümleri, ilgili kanunlarda gerekli değişiklikler yapılıncaya ve en geç 31 Aralık 2006 tarihine kadar uygulanır" hükmü bulunsa da, bu hükmün uzlaştırma yönünden uygulanması gerekli değildir. Çünkü, uzlaştırmayı düzenleyen kanun hükümlerinde diğer kanun hükümlerine aykırı bir düzenleme bulunmamaktadır.

31 İcra ve İflâs Kanununun 352/a maddesinde düzenlenen ceza kararnamesi, Ceza Muhakemesi Kanununa paralel olarak yürürlükten kaldırılmıştır (RG 01.06.2005, Sa. 25832, Mükerrer). İcra suçlarında uzlaştırmaya başvurulması suretiyle yargılamanın kısa sürede bitirilmesi sağlanabilecektir.
} 
sayede, icra mahkemelerinin iş yükünde de önemli bir azalma olur ${ }^{32}$. İcra ve İflâs Kanununun 352. maddesinin 2. fikrasında, takibi şikâyete bağlı suçlarda dava ve cezanın 354. maddede yazılı sebeplerle düşeceğinin, tetkik merciinin kararında belirtileceği öngörülmüştür. Bu hükmün amacı, failin, mağdurun zararını gidermeye teşvik edilmesi ve böylece tarafların uzlaşmasıdır. Söz konusu hükmün hükûmet gerekçesinde bu husus şu şekilde ifade edilmiştir: "Şikâyetten vazgeçme veya şikâyetin geri alınması ahlâka aykırı olmamak kaydıyla şarta bağlanabilir. Vazgeçme veya geri almanın, mağduriyetin giderilmesi şartına bağlanması, 21. Yüzyılda ceza hukukunun en önemli konularından biri olan 'mağdurun korunmasına' hizmet eder. Bu nedenle maddeye 'takibi şikâyete bağlı suçlarda dava ve cezanın 354'üncü maddede yazılı sebeplerle düşeceği kararda belirtilir' şeklinde bir hüküm eklenerek, söz konusu olanağın ilgiliye hatırlatılması amaçlanmıştır"33. İ́cra ve İflâs Kanununun bu hükümleri dikkate alındığında, icra ceza mahkemelerinin uzlaştırma yoluyla birçok davanın düşmesini sağlayacağı açıkça görülmektedir.

Uzlaştırmaya başvurulabilecek suçlardan bir diğeri, 3167 sayılı Çekle Ödemelerin Düzenlenmesi ve Çek Hamillerinin Korunması Hakkında Kanunun $^{34}$ 16. maddesinde düzenlenen karşıllkssı çek keşide etme suçudur. Buna göre, süresinde ibraz edilmiş olmasına rağmen, yeterli karşıllı̆g 1 bulunmaması nedeniyle bir çekin ödenmemesi suçtur. Karşılıksız çek keşide etme suçu, takibi şikâyete bağlı bir suçtur. Bu suçun faili, karşılıksız çeki keşide eden kişidir. $\mathrm{Bu}$ suçtan dolayı soruşturma ve kovuşturma yapılabilmesi için, çeki ibraz ederek karşılıksızlığını tespit ettiren hamilin, müracaat hakkına dayanarak çeki geri alan (ve ciro zincirinde gözüken) cirantalardan birinin veya kanunî veya akdî teminatı nedeniyle çek bedelini tamamen ödeyen muhatap bankanın şikâyette bulunması gerekir ${ }^{35}$ (Çek K. m. 16b). Bu suç nedeniyle dava açıldığ 1 takdirde, mahkeme ${ }^{36}$, suçun mağdurları ile suçun failini uzlaştırmaya yönlendirebilir. Faille uzlaşan hamil, şikâyetten her zaman vazgeçebilir ${ }^{37}$; bu durumda görülmekte olan dava düşer. Çek Kanununun 16c maddesi de uzlaşmayı desteklemektedir. Bu

32 İcra ve İflas Kanununun 331 ilâ 353. maddelerinde yazılı suçlarda yetkili ve görevli mahkeme, icra takibinin yapıldığ 1 yerdeki icra mahkemesidir (İ̈K m. 346, III; 348). İcra mahkemeleri, Ceza Muhakemesi Kanununun 253 ve devamındaki maddelerde belirtilen usulü uygulayacaktır.

${ }^{33}$ İcra ve İflâs Kanununda Değişiklik Yapılmasına Dair Kanun Tasarısı ve Adalet Komisyonu Raporu (1/550), Dönem 22, Yasama Y1l1 1, Sira Sayıs1 225.

${ }^{34}$ RG 3.4.1985, Sa. 18714.

${ }^{35} \mathrm{Bu}$ konuda geniş bilgi için bkz. Abuzer Kendigelen, Çek Hukuku, İstanbul 2004, s. 280 vd.

${ }^{36}$ Karşıllısız çek keşide etme suçunda yetkili ve görevli mahkeme, çekin ibraz edildiği ya da keşide edildiği veya şikâyetçinin yerleşim yerinin bulunduğu yer asliye ceza mahkemesidir (Çek K. m. 16b).

37 Hamil, hükmün kesinleşmesinden sonra dahi şikâyetten vazgeçebilir; ancak bu hâlde uzlaşma, mahkeme kararı olmadan gerçekleşir ve hüküm bütün cezaî sonuçları ile ortadan kalkar (Çek K. m. 16b, III). 
maddeye göre, dava açılmasıyla hükmün kesinleşmesi arasındaki dönemde (hatta hükmün kesinleşmesinden sonra), çekin karşılıksız kısmının, temerrüt faizinin ve kademeli olarak artan oranlardaki (\%12'den \%20'ye kadar) çek tazminatının hamile veya hamile ödenmek üzere muhatap bankaya ödenmesi hâlinde ceza davası açılmaz; dava açılmışsa düşer veya hüküm verilmişse, bütün cezaî sonuçlarıyla ortadan kalkar ${ }^{38}$.

Yargitay Ceza Genel Kurulu 5.7.2005 tarihinde, Türk Ceza Kanunundaki uzlaştırmaya ilişkin hükümlerin, 3167 sayılı Kanunun hükümleriyle çatıştığ1 gerekçesiyle ve 5349 sayılı Kanunun geçici 1 . maddesine dayanarak, karşılıksız çek keşide etme suçlarında, 3167 sayılı Kanunda gerekli değişiklikler yapılıncaya ve en geç 31 Aralık 2006 tarihine kadar, uzlaștırmaya bașvurulmasına gerek olmadığına karar vermiștir. Yargitay Ceza Genel Kurulunun bu kararı şu şekildedir ${ }^{39}$ :

"Karşılıksız çek keşide etmek suçundan sanığın, 3167 sayılı Yasanın 16/1. maddesi uyarınca 1 yıl hapis cezas ile cezalandırılmasına ve 1 yıl süre ile bankalarda çek hesabı açmak ve çek keşide etmekten yasaklanmasına ilişsin, İstanbul 7. Asliye Ceza Mahkemesince verilen 15.05.2001 gün ve 989-2233 sayılı hüküm, sanık tarafindan temyiz edilmekle, dosyayı inceleyen Yargitay 10. Ceza Dairesince 24.03.2003 gün ve 8340-3287 sayı ile; '...08.03.2003 tarih 25042 say1lı Resmi Gazete'de yayımlanarak yürürlüğe giren 3167 sayılı Çekle Ödemelerin Düzenlenmesi ve Çek Hamillerinin Korunması Hakkında Yasada Değişiklik yapılmasına ilişsin 4814 sayılı Yasanın Geçici 1 ve 2. maddeleri ile TCY.nın 2/2. maddesi hükmü nazara alınarak uygulama yapılmasında yasal zorunluluk bulunması' gerekçesiyle bozulmuş, Bozmaya uyan Yerel Mahkemece 16.10.2003 gün ve 348-713 sayı ile; 4814 sayılı Yasayla değişik 3167 sayılı Yasanın 16. maddesi uyarınca sanığın çek tutarı olan, 316.000.000 lira ağır para cezasıyla cezalandırılmasına, 1 yıl süre ile çek keşide etmekten ve bankalarda çek hesabı açmaktan yasaklanmasına karar verilmiş, Sanık müdafi tarafından temyiz edilen bu hüküm, dosyayı inceleyen Yargıtay 10. Ceza Dairesince 10.06.2005 gün ve 1236-5918 say1 ile onanmıştır. Yargitay C.Başsavcılığınca 17.06.2005 gün ve 26558 sayı ile, '01.06.2005 tarihinde yürürlüğe giren 5237 sayılı Türk Ceza Yasası'nın 73. maddesi, soruşturulması ve kovuşturulması şikayete bağlı bulunan suçlarda yeni bir kurum olarak getirdiği uzlaşma yöntemini öncelikle uygulanmasını zorunlu olarak öngörmüş ve 5271 sayılı Ceza Muhakemesi Yasası'nın 253 ve 254. maddelerinde ise uzlaşma usulü düzenlenmiştir.-Karşılıksız çek keşide etmek suçu şikayete bağlı suçlardandır. Gerek yeni maddi ceza, gerek ceza usulü yasalarımız şikayete bağlı suçlarda uzlaşma hükümlerine tabi olmama yönünde istisna kabul etmemiştir. Uzlaşma şikayete bağlı tüm suçlarda

${ }^{38}$ Kendigelen s. 284.

${ }^{39}$ CGK 5.7.2005, 10-84/90 (http://www.kazanci.com.tr). 
uygulama alanı bulacaktır. -Buna göre şikayet vaki olduğunda CYY'nın 253. maddesindeki usül gereği olarak uzlaşma süreci başlatılacaktır. Bu süreçte yasal otorite yönetiminde çek bedelinin veya karşılıksız kalan kısmının önemli bir miktarının ödenmesinin fail tarafindan kabul edilmesi ve buna şikâyetçinin rıza göstermesi ve sonucunda da tarafların uzlaşıp failin uzlaşılan miktarı ve masrafları ödemesi soruşturmayı ve kovuşturmayı sona erdirecektir. $\mathrm{Bu}$, sanığa yeni ceza yasasının tanıdığı yeni bir imkândır. Zararın uzlaşılan miktarının ve giderlerinin ödenmesi şikâyetten vazgeçme yanında ayrı bir takipsizlik veya davanın düşme nedenidir. Hiçbir zaman soruşturma ve kovuşturmada şikâyetten vazgeçme hakkını kısıtlayan bir durum yaratmamaktadır. Uzlaşma olmadığı takdirde sonraki her evrede şikâyetçi vazgeçme hakkını kullanabilecektir. Yine fail çek tutarının tamamını veya karşılıksız kalan kısmını evrelerine göre değişen tazminat ve gecikme faizini ödemesi halinde ceza davası düşecek veya tüm sonuçlarıyla ortadan kalkacaktır. Görülmektedir ki uzlaşma hükümleri, 3167 sayılı Yasa'nın 'hükmün kesinleşmesinden sonra şikâyetten vazgeçildiğinde de hüküm bütün cezai sonuçlarıyla ortadan kalkar' şeklinde 16/b maddesinin 3 . fikrası ve 'Davanın açılmasına engel olan davayı düşüren ve cezayı ortadan kaldıran nedenler' başlıklı 16/c maddesinin uygulanmasına engel değildir. Uzlaşma ile 3167 sayılı Yasanın 16/b ve 16/c maddeleri çatışmamaktadır. Diğer bir ifade ile uzlaşma hükümleri $16 / b$ ve 16/c maddelerine aykırı değildir. Yani, onların yerine geçip onları ortadan kaldıran, uygulama yeteneğini yok eden düzenleme içermemektedir. Zira, şikâyet vaki olduğunda öncelikle uzlaşma hükümlerinin uygulanması yasal zorunluluğu yerine getirilecek; uzlaşılmadığ takdirde $16 / \mathrm{b}$ ve $16 / \mathrm{c}$ maddelerindeki yetki ve imkânlar özgür irade ile kullanılabilecektir. Bu durumda uzlaşma faile hatta şikâyetçiye tanınan yeni bir imkândır. İhtilafın kısa zamanda tarafların özgür iradeleriyle ve adli mercilerin daha fazla meşgul edilmeyerek sonuçlandırılması amacını gütmektedir. -Türk Ceza Yasasının Yürürlük ve Uygulama Şekli Hakkında Yasada Değişiklik Yapılmasına Dair 5349 sayılı Yasanın geçici 1. maddesinin 'Diğer yasaların, 5237 sayılı Türk Ceza Yasasının 1. kitabında yer alan düzenlemelere aykırı hükümleri, ilgili yasalarda gerekli değişiklikler yapılıncaya ve en geç 31 Aralık 2006 tarihine kadar uygulanır' şeklindeki hükmünün uzlaşma kurumu yönünden uygulama alanı bulunmamaktadır. Zira, uzlaşma yukarıda açıklandığı üzere, 3167 sayılı Yasaya aykırı bir düzenleme değildir. -Uzlaşma, yeni yapılan şikayetlerde ve sürdürülen soruşturma ve kovuşturmalarda mutlaka öncelikle uygulanması zorunlu bir maddi ceza ve ceza usulü kurumudur. Uzlaşma için zararın tamamının ödenmesi de şart değildir. Şikâyetçi tarafından kabul edilmesi halinde önemli bir kısmı üzerinde anlaşma ve ödeme yeterli olacaktır. Karşılıksız çek keşide etmede de aynı şekilde çekin tam tutarı veya karşılıksız kalan kısmının tamamının ödenmesi şart olmayıp uzlaşılan önemli bir kısmının örneğin, 10 milyarlık çek bedelinin 6 milyarlık kısmının ödenmesiyle uzlaşma amacına ulaşmış olacaktır. -Uzlaşmada temel düşünce, 
suçu kabul eden failin, suçtan zarar görenin zararının tümünü veya önemli bir kısmını ödemeyi kabul etmesi ve masraflarla birlikte ödemesidir. Burada dikkat edilecek nokta şikâyetçinin, suçun kendisine verdiği zararın bir kısmından fedakârlık ederek önemli bir kısmının ödenmesini kabul etmesi mümkün hale getirilmiştir. Uzlaşma sağlanamaması keyfiyeti, daha sonra şikâyetten vazgeçme hakkının kullanılmasına engel teşkil etmediği gibi, şüpheli ve sanığın karşılıksız çekin veya karşı1lıksız kalan kısmının tamamının tazminat ve gecikme faiziyle ödeyerek suçtan ve cezadan kurtulma imkânını ortadan kaldırmamaktadır. -Sonuç olarak uzlaşma, 3167 sayılı Yasanın 16/b ve 16/c maddelerine aykırı değildir. Soruşturmada ve davada ayrı bir uygulama yeri vardır. Yeni Ceza Yasasının getirdiği bu imkândan sanığın mahrum edilmesine yol açacak yorum ve uygulama uzlaşma kurumunun temel fikrine aykırılık oluşturacaktır.' gerekçeleriyle itiraz yasayoluna başvurularak, Yargıtay 10. Ceza Dairesinin onama kararının kaldırılması, 5271 sayılı CYY.nın 254. maddesi uyarınca uzlaştırma işlemleri yapılmak üzere, Yerel Mahkeme hükmünün bozulması isteminde bulunulmuştur. -Dosya Birinci Başkanlığa gönderilmekle, Yargıtay Ceza Genel Kurulunca okunup, konu müzakere edilmiș ve açıklanan karara varılmıştır. -KARAR : Sanığın karşılıksız çek keşide etmek suçundan, 3167 sayılı Yasanın 16/1. maddesi uyarınca çek bedeli olan 316.000.000 lira ağır para cezasıyla cezalandırılmasına,1 yıl süre ile çek keşide etmekten ve bankalarda çek hesabı açmaktan yasaklanmasına karar verilen somut olayda; Özel Daire ile Yargıtay C.Başsavcıllğı arasında, sübut ve nitelendirmede herhangi bir uyuşmazlık bulunmayıp, çözülecek sorun, 5237 ve 5271 sayıl Yasalarla hukukumuza giren uzlaşma kurumunun, 5349 sayılı Yasa ile 5252 sayılı Yasaya eklenen, Geçici 1. maddedeki düzenleme karşısında, karşılıksız çek keşide etmek suçlarında uygulama olanağının bulunup bulunmadığı noktasında toplanmaktadır. ...5237 sayılı Yasanın; 'Özel kanunlarla ilişki' başlığını taşıyan 5. maddesindeki; 'Bu Kanunun genel hükümleri, özel ceza kanunları ve ceza içeren kanunlardaki suçlar hakkında da uygulanır.' hükmü uyarınca uzlaşmanın, koşullarının bulunması halinde gerek TCY.nda, gerekse ceza hükmü taşıyan Özel Yasalarda yer alan suçlar bakımından uygulanacağı konusunda bir kuşku bulunmamakta ise de, 5349 sayılı Yasa ile 5252 sayılı Yasaya eklenen Geçici 1. madde ile diğer yasaların TCY.nın Birinci Kitabında yer alan düzenlemelere aykırı hükümlerinin uygulanmasına ilgili yasalarda değişiklik yapılıncaya ve en geç 31 Aralık 2006 tarihine kadar devam olunacağından, 3167 sayılı Yasa hükümlerinin bu kapsama girip, girmeyeceği, başka bir deyişle, aykırı düzenlemeler içerip içermediğinin de değerlendirilmesinde zorunluluk bulunmaktadır. -3167 sayılı Çekle Ödemelerin Düzenlenmesi ve Çek Hamillerinin Korunması Hakkında'ki Yasanın 16. maddesinde karşı1ıksız çek keşide etme suçu düzenlenmiş olup, madde uyarınca karşılıksız çek keşide edenler, çek bedeli kadar ağır para cezasıyla, mükerrirler ise bir yıldan beş yıla kadar hapis cezasıyla cezalandırılacaklardır. -Aynı Yasanın 
16/a maddesinde, karşılıksız kalan kısmına ibraz tarihinden itibaren 3095 sayılı Yasaya göre faiz yürütüleceği belirtilmiş, 'Soruşturma ve kovuşturma usulü, görevli ve yetkili mahkeme' başl1klı 16/b maddesinde; maddede yazılı suçtan soruşturma ve kovuşturma yapılmasının şikayete bağlı bulunduğu, hükmün kesinleşmesinden sonra şikayetten vazgeçildiğinde de, hükmün bütün sonuçlarıyla birlikte ortadan kaldırılacağı, hükmüne yer verilip, 'Davanın açılmasına engel olan, davayı düșüren ve cezayı ortadan kaldıran nedenler' başlıklı 16/c maddesinde; düzeltme hakkının kullanılması veya henüz dava açılmadan, çek tutarı veya karşıllksız kalan kısmının \%12 tazminat ve faiziyle birlikte ödenmesi halinde ceza davası açılmayacağı, dava açıldıktan sonra hüküm verilinceye kadar \%15 tazminat ve faizle birlikte ödeme halinde, hüküm verildikten sonra, hüküm kesinleşinceye kadar \%18 tazminat ve faizle birlikte ödeme halinde ceza davasının düşeceği, hüküm kesinleştikten sonra $\% 20$ tazminat ve faizle birlikte ödeme halinde ise hükmün bütün cezai sonuçlarıyla birlikte ortadan kaldırılacağ 1 ayrıntılı olarak düzenlenmiştir. -Görüldüğü üzere, esasen 3167 sayılı Yasada da uzlaşmaya ilişkin hükümler yer almaktadır, ancak; her iki yasanın getirdiği sistem ve olanaklar arasında çeşitli farklılıklar bulunmaktadır, Şöyle ki;

1. Uzlaşma için failin mutlak olarak suçunu kabul etmesi gerektiği halde, 3167 sayılı Yasa hükümleri uyarınca ödeme ile sonuç alınması için failin suçunu kabul etmesi gerekmez,

2. Uzlaşmada, mağdurun zararının tümünün veya büyük bir kısmının ödenmesi zorunlu olduğu halde, 3167 sayılı Yasaya göre şikayetten vazgeçme, failin hiç ödeme yapmaması halinde de mümkündür,

3. Uzlaşma için fail ve mağdurun anlaşmalarında zorunluluk bulunduğu halde, 3167 sayılı Yasaya göre fail mağdurdan bağımsız olarak ödemede bulunabileceği gibi, mağdur da bağımsız olarak şikayetten vazgeçebilir.

4. Uzlaşma hüküm kesinleşinceye kadar yapılabilir, ancak karşılıksız çek keşide etme suçunda mağdur ve fail hüküm kesinleştikten sonra da anlaşabilirler,

5. Uzlaşma, yalnızca suçtan zarar göreni gerçek kişi veya özel hukuk tüzel kişisi olması halinde mümkün olup, 3167 sayılı Yasada anlaşma için bu tür bir sınırlama bulunmamaktadır,

6. Uzlaşmadan sadece uzlaşan fail yararlanabilmekte, diğer şerikler yararlanamamakta, 3167 sayılı Yasada ise, ödeme halinde diğer failler de yararlanmaktadır.

7. Fail ile mağdur arasında uzlaşma sağlandıktan sonra, zararın giderilmeyen bölümü için, icra takibi yapılamayacağı gibi, hukuk mahkemesinde de dava açılamaz, oysa suçtan zarar gören, şikayetinden 
vazgeçtiği sırada, şahsi haklarından vazgeçtiğini açıklamadıkça, bu konuda icra takibi yapması ve hukuk mahkemesinde dava açması mümkündür.

$\mathrm{Bu}$ açıklamalardan da anlaşıldığı gibi, ilk dört hususun birbirinin tamamlayıcısı oldukları, birinin diğerine aykırılık oluşturmadığı savunulabilirse de, diğer hususlar 5237 sayılı TCY.nın Birinci Kitabının 73/8. maddesinde düzenlenen uzlaşma kurumuna açıça aykırılık oluşturmaktadır. -11.5.2005 gün ve 5349 sayılı Yasanın 6. maddesi ile 5252 sayılı Yasaya eklenen Geçici 1. maddesi uyarınca, diğer yasaların, 5237 sayılı Yasanın Birinci kitabında yer alan düzenlemelere aykırı hükümleri ilgili yasalarda gerekli değişiklik yapılıncaya ve en geç 31 Aralık 2006 tarihine kadar uygulanacağından, Yargıtay C.Başsavcılığının, karşılıksız çek keşide etmek suçundan sanığın mahkumiyetine ilişkin hükmün, uzlaşma hükümlerinin uygulanması gerektiği görüşüyle bozulması yönündeki görüşünde isabet bulunmamaktadır. -Bu itibarla Yargıtay C.Başsavcılığının itirazının reddine karar verilmelidir. -Çoğunluk görüşüne katılmayan Kurul Başkanı; '5237 sayılı TCY.nın 73/8. maddesinde uzlaşmanın koşulları, 5271 sayılı CYY.nın 253,254 ve 255. maddelerinde ise uzlaşmanın yöntemi ve sonuçları ayrıntılı olarak düzenlenmiştir. Hukukumuza 5237 ve 5271 sayılı Yasalarla giren bu yeni kurum, düzenlenişi itibariyle hem maddi, hem de usul hukuku müessesesi özelliklerini taşıyan karma bir nitelik göstermektedir. 5237 sayılı Yasanın 73/8. maddesi uyarınca uzlaşma şikayete bağlı bulunan ve suçtan zarar göreni gerçek kişi veya özel hukuk tüzel kişisi bulunan tüm suçlar açısından geçerli olup, maddede başkaca bir ek koşul veya sınırlandırıcı herhangi bir husus yer almamaktadır. Hukukumuzda, bazı suçlar açısından, uzlaşmaya benzer düzenlemeler yer almakta ise de, mağdurun zararının giderilmesi ve onarıcı adalete yardımcı olan bu normların TCY.nın 73/8. maddesinde düzenlenen uzlaşma ile bir ilgisi ve bu düzenlemeyi etkileyici veya düzenlemeden etkilenici herhangi bir yönü bulunmamaktadır. Uzlaşmanın hedefi suçun işlenmesinden sonra fail ve mağdur arasında meydana gelen çekişmeyi, bir arabulucunun girişimini sağlayarak çözmek ve adaleti sağlamaktır. Failin neden olduğu zararın giderilmesi, fail-mağdur arasındaki barış, uzlaşmanın asıl unsurunu oluşturur. Bu haliyle uzlaşma faile ve mağdura yeni bir imkan tanıyarak, ihtilafın kısa zamanda tarafların özgür iradeleriyle ve adli mercilerin daha fazla meşgul edilmeyerek sonuçlandırılmasını amaçlamaktadır. Fail-mağdur arasındaki uzlaşma suçun faili bakımından cezanın 'özel önleme' fonksiyonuna yardım ettiği gibi mağdurun ve genel olarak kamunun da yararlarının korunmasını sağlar. Fail, uzlaşma ile, işlediği suçun sorumluluğunu kabul edip üstlenerek ve sonuçlarını da gidererek toplumla yeniden bütünleşme olanağını elde etmiş olur. Böylece failin ceza sorumluluğunu tespit ve zararın giderilmesi için gereken yapılmış bulunacağından, mağdur bakımından da adalet yerine getirilmiş olur. Failmağdur arasındaki uzlaşma, bundan başka, kamuda da, fiille ihlâl edilmiş 
olan hukuk kurallarının geçerliliğini vurgulamış ve dolayısıyla kamusal barışın yeniden kurulmasına hizmet etmiş olur. Fail ve mağdur arasındaki uyuşmazlığı, ceza yargılaması dışına çıkarıp, karşılıklı anlaşma çerçevesinde çözmeyi amaç edinen uzlaşma, devreye girdiğinde, gerek ceza gerekse hukuk yargılamasını devre dışı bırakır, diğer bir anlatımla uzlaşmanın devreye girmesiyle soruşturmanın, yargılama aşamasında ise kovuşturmanın sonraki aşamalarına geçilemez. -Bu açıklamalar ışı̆̆ında somut olay değerlendirildiğinde, TCY.nın $73 / 8$ ve CYY.nın 253 vd. maddelerinde düzenlenen uzlaşma hükümleri, 3167 sayılı Yasanın 16/b ve 16/c maddelerinin yerine geçip onları ortadan kaldıran ve uygulama yeteneğini yok eden düzenlemeler olmayıp, bu düzenlemeleri de kapsayan, fail ve mağdura sağlanan hak ve yetkileri genişletici ve tamamlayıcı hükümler olup, 3167 sayılı Yasa hükümlerine aykırılık oluşturmadığı gibi, onlarla da çatış̧mamaktadır. -Bu nedenle şikayet bulunduğunda, öncelikle uzlaşma hükümlerinin uygulanması yasal zorunluluğu yerine getirilecek; uzlaşılmadığı takdirde 3167 sayılı Yasanın 16/b ve 16/c maddelerindeki yetki ve olanaklar özgür irade ile kullanılabilecektir. Yeni Ceza Yasasının getirdiği bu olanaktan sanığın yoksun bırakılmasına yol açacak çoğunluk görüşünün, uzlaşma kurumunun temel yapısına da aykırılık oluşturacağı düşüncesinde olduğumdan, Yargıtay C.Başsavcılığı itirazının kabulü gerektiği görüşündeyim,' gerekçesiyle, Diğer beş kurul üyesi ise, haklı nedenlere dayanan Yargıtay C.Başsavcılığ itirazının kabulü gerektiği görüşüyle, Karşı oy kullanmışlardır. -KARAR: Açıklanan nedenlerle, 1-Yargıtay C.Başsavcılığı itirazının REDDİNE, 2-Dosyanın Mahkemesine gönderilmek üzere Yargitay C.Başsavcılığına tevdiine, ilk müzakerede yasal çoğunluk sağlanamadığından 05.07.2005 günü yapılan ikinci müzakerede oyçokluğu ile karar verildi."

Kanımca, Yargıtay Ceza Genel Kurulunun bu kararı uzlaştırma kurumunun amacıyla bağdaşmamaktadır. Türk Ceza Kanununun uzlaştırmayı düzenleyen hükümleri, 3167 sayılı Kanunun hükümleriyle çelişmemekte, tam tersine bu hükümleri tamamlayarak, failin ve mağdurun haklarını genişletmektedir. Uzlaştırmaya başvurulmasının tamamen gönüllü olduğu dikkate alındığında, karşılıksız çek keşide etme suçunun taraflarını bu imkândan mahrum bırakmanın hiçbir haklı dayanağı olmadığ 1 anlaşılır. $\mathrm{Bu}$ nedenle, karşıllısız çek keşide etme suçlarında da uzlaştırmanın uygulanmasında tereddüt edilmemelidir. Uygulamada bu suçlarda uzlaştırma yolundan büyük yararlar elde edilmesi mümkündür. Yargitay Ceza Genel Kurulunun kararına muhalif kalan görüşler daha isabetlidir.

Nihayet, fikrî mülkiyet hukukundaki suçlarda da uzlaştırmaya başvurulabilir. Fikir ve Sanat Eserleri Kanununun ${ }^{40} 71,72,73$ ve 80. maddelerinde, hak sahiplerinin malî ve manevî haklarına karşı yapılmış

${ }^{40}$ RG 31.12.1951, Sa. 7981. 
tecavüzlerle ilgili suçlar yer almaktadır. Bu maddelerden 71. madde, eser sahiplerinin manevî haklarının ihlâli, 72. madde hak sahiplerinin malî haklarının ihlâli, 80. madde bağlantılı hak sahiplerinin haklarına tecavüzle ilgili suçları düzenlemektedir. Bu maddelerde sayılı suçlar takibi şikâyete bağlı olduğundan, uzlaştırmaya konu olabilir (FSEK m. 75). 551 sayılı Patent Haklarının Korunması Hakkında Kanun Hükmünde Kararnamenin ${ }^{41}$ 73/A maddesine göre, bu maddenin a, b, c bentlerinde yazılı suçlardan dolayı kovuşturma yapılması şikâyete bağlıdır. Dolaysıyla bu suçlarda da uzlaştırmaya başvurmak mümkündür. Benzer şekilde, 556 sayılı Markaların Korunmas1 Hakkında Kanun Hükmünde Kararnamenin ${ }^{42}$ 61/A maddesinde sayılan suçlardan dolayı kovuşturma yapılması şikâyete bağlı olduğundan uzlaştırmaya başvurulabilir.

Mukayeseli hukukta uzlaştırma sadece takibi şikâyete bağlı suçlarla sınırlı olmayıp, daha ağır suçlarda da uzlaştırmaya başvurulabilmektedir ${ }^{43}$. Hukukumuzda uzlaştırmanın geliştirilmesi bakımından, takibi şikâyete bağlı olmayan (re'sen kovușturulan) bazı suçlarda da uzlaștırmaya başvurulmasina izin verilmelidir. Türk Ceza Kanununda uzlaştırmaya uygun olan başka suçlar da bulunmaktadır. Türk Ceza Kanunundaki suçların taranarak, uzlaştırmaya uygun olanların belirlenmesi ve uzlaştırma kapsamına alınması yararlı olacaktır. Örneğin, trafik kazalarından doğan uyuşmazlıkların uzlaştırmayla başarılı bir şekilde çözülmesi mümkündür. Oysa, Türk Ceza Kanununda yer alan trafik güvenliğini tehlikeye sokma (TCK m. 179,2-3) ve trafik güvenliğini taksirle tehlikeye sokma (TCK m. 180) suçları takibi şikâyete bağlı suçlar olmakları için uzlaştırmaya konu olamazlar. Bu suçların uzlaştırma kapsamına alınması gerekir.

Türk Ceza Kanununda uzlaştırmanın kabul edilmesiyle, önödemenin sınırı belli ölçüde daralmış ve önödemenin yerini kısmen uzlaştırma almıştır $^{44}$. Önödemeye, uzlaştırma kapsamındaki suçlar dışında, yalnız adlî para cezasını gerektiren veya kanun maddesinde öngörülen hapis cezasının yukarı sınırı üç ayı aşmayan suçlarda başvurulabilir (TCK m. 75).

\section{Ceza Muhakemesi Kanununa Göre Uzlaştırmanın İșleyiși}

Uzlaştırmanın usulü $^{45}$, Ceza Muhakemesi Kanununun 253 ilâ 255. maddelerinde düzenlenmiştir ${ }^{46}$. Uzlaştırmaya gerek soruşturma, gerek

\footnotetext{
${ }^{41}$ RG 27.06.1995, Sa. 22326.

${ }^{42}$ RG 27.06.1995, Sa. 22326.

${ }^{43}$ Brown, Marriott s. 300; Zafer s. 730.

${ }^{44}$ Bkz. hükûmet gerekçesi (T.C. Başbakanlık Kanunlar ve Kararlar Genel Müdürlüğü s. 66).

45 Mağdur-fail uzlaştırmasının genel olarak işleyişi hakkında bilgi için bkz. Özbek, Arabuluculuk Uygulaması s. $134 \mathrm{vd}$.

${ }^{46}$ Ceza Muhakemesi Kanununda uzlaștırmanın düzenlemesiyle ceza kararnamesine gerek kalmadığından, TBMM Adalet Alt Komisyonunda Ceza Kararnamesine ilişkin hükümler
} 
kovuşturma evresinde (kamu davası sırasında ${ }^{47}$ ) başvurulabilir ${ }^{48}$.

\section{A) Uzlaştırmanın Usulü ve Koşulları}

\section{I- Uzlaştırmaya Başvurulması, Failin Belirlenmesi ve Sorumluluğunu Kabullenmesi}

Yukarıda görüldüğü üzere, ceza muhakemesi sürecinin her aşamasında uzlaştırmaya başvurulabilmektedir. Önödemede olduğu gibi, uzlaşmaya tâbi olduğu soruşturma dosyasından açıkça anlaşılan işlerde, Cumhuriyet savcisının uzlaşmaya başvurmadan kamu davası açması hâlinde, iddianamenin iadesine karar veriliir ${ }^{49}$ (CMK m. 174,1/c). Kanımca, bu hâlde iddianamenin iadesine karar verilmesi isabetli değildir. Zira, iddianamenin iadesi, Ceza Muhakemesi Kanununun 170. maddesinde belirtilen unsurların iddianamede bulunmaması, iddianamenin eksik olması hâlinde, mevcut eksikliklerin tamamlaması için öngörülmüştür. Böylece uygulamada, yeterli bir soruşturma yapmadan kamu dava açılması önlenebilecektir ${ }^{50}$. İddianamenin iadesinde amaç, davanın bir duruşmada sonuçlanmasını sağlamaktır. Oysa mahkemenin, kovuşturma aşamasında uzlaştırmaya başvurmas1 mümkündür. Böyle bir imkân varken, iddianamenin iadesi mahkemeye zaman kazandırmayacaktır. Bu durumda mahkeme, iddianameyi iade etmek yerine, 253. madde belirtilen usule göre uzlaştırmaya kendisi başvurmalıdır ${ }^{51}$ (CMK m. 254,1).

Soruşturma evresinde uzlaştırmaya başvurulmasını isteyen Cumhuriyet savc1s1, öncelikle faili davet ederek, suçtan dolayı sorumluluğunu kabul edip etmediğini sorar (CMK m. 253,1). Fail, suçu ve fiilinden doğmuş olan maddî ve manevî zararın tümünü veya bunun büyük bir kısmını ödemeyi veya zararları gidermeyi kabul ederse, durum, mağdura veya varsa vekiline veya kanunî temsilcisine bildirilir ${ }^{52}$ (CMK m. 253,2). Uzlaştırmaya esas olan maddî olayların, mağdur ve fail tarafından kabul edilmesi, uzlaştırmaya başvurulmasının ön koşuludur ${ }^{53}$. Bu tür bir ortak kabul olmadan, uzlaştırma

kanun tasarısında çıkarılmıştır.

${ }^{47}$ Ceza Muhakemesi Kanunun yürürlüğe girmesinden önce şahsi dava usulüne göre yürütülen davalar kamu davası olarak sürdürülecek ve özel kanunlarda öngörülen şahsi davalar kamu davasına dönüşecektir. Bu davalarda uzlaşma hükümleri uygulanacaktır (Ceza Muhakemesi Kanununun Yürürlük ve Uygulama Şekli Hakkında Kanun m. 9).

${ }^{48}$ Avrupa Konseyi Bakanlar Komitesinin tavsiye kararında belirlenen ilkelere göre, ceza muhakemesinin her aşamasında uzlaştırmaya başvurulması mümkün olmalıdır (Committee of Experts on Mediation in Penal Matters s. 5).

${ }^{49} 5353$ sayılı kanunla değişik (RG 01.06.2005, Sa. 25832).

${ }^{50}$ Erdener Yurtcan, Ceza Yargllaması Hukuku, İstanbul 2005, s. 387.

${ }^{51}$ Aksi görüş için bkz. Kaymaz, Gökcan s. 110.

${ }^{52}$ Cumhuriyet savcısı faille bizzat görüşmelidir. Failin uzlaştırmayı kabul etmesinden sonra mağdurla görüşülmelidir. Mağdurun Cumhuriyet savcısıyla bizzat görüşmesi şart olmayıp, vekili veya kanunî temsilcisi aracılığıyla uzlaştırmayı kabul ya da reddetmesi mümkündür.

${ }^{53}$ Committee of Experts on Mediation in Penal Matters s. 6. 
sürecinde anlaşmaya varılması çok güçtür. Ancak kanımca, bu kabule ilave olarak failin suçu ikrar etmesi şart değildir ${ }^{54}$. Failin, suçtan dolayı kısmen dahi olsa sorumlu olduğunu kabul etmesi ve mağdurun zararını gidermek istediğini bildirmesi yeterlidir ${ }^{55}$. Önemli olan, failin uzlaşmaya yönelik hür iradesinin varlığıdır. Aksi hâlde, uzlaştırma gerçekleşmez ve kamu davası açılırsa, failin suçu ikrar etmiş olmasının, aleyhine delil olarak kullanılması tehlikesi ortaya çıkar. Her ne kadar, Ceza Muhakemesi Kanununun 253. maddesinin 6. fikrası, uzlaşma müzakerelerinin gizli olduğunu belirtmişse de, gizlilik uzlaşma müzakereleriyle sınırlı olup, sadece müzakere sürecini kapsar. Oysa gizlilik, failin uzlaşmayı kabul etmesinden itibaren başlamalıdır. Yapılacak bir kanun değişikliğiyle, failin uzlaștırmaya başvurmak için suçu kabullenmiş olmasının da aleyhine delil olarak kullanılamayacağı belirtilmelidir. Böyle bir değişiklik yapılana kadar, Kanunun gizliliğe ilişkin hükmünün kıyasen, failin suçu kabul etmesi hâlinde de uygulanması isabetli olur. Bilindiği gibi, ceza koyan veya cezayı ağırlaştıran kurallarda kıyas (analogie) caiz değildir. Ancak muhakeme hukukunda, bu yasağa aykırılık olmadığı için kıyas mümkündür ${ }^{56}$. Muhakeme hukukunda, kıyas yoluyla uygulanacak norm istisnai ve sınırlayıcı değilse, kişi hak ve hürriyetleri aleyhine bir kural içermiyorsa kıyasın caiz olduğu kabul edilir. Gizliliğin amacı, uzlaşma müzakerelerinin zorunlu bir unsuru olması ve failin haklarını koruyucu etkisi göz önüne alındığında, kıyas yoluyla genişletilmesinin mümkün olduğu anlaşılır.

Uzlaştırmaya başvurulabilmesi için failin suçu kabul etmesiyle yetinilmemeli, suçun fail tarafindan işlendiğine dair yeterli şüphe de bulunmalı; yani fail doğru tespit edilmelidir ${ }^{57}$. Bu hususta, Türk Ceza Kanununun 170. maddesinde belirtilen "yeterli şüphe" kavramından yararlanılabilir. Bu maddeye göre, kamu davası açabilmek için, soruşturma evresi sonunda toplanan deliller, suçun o fail tarafindan işlendiği hususunda yeterli şüphe oluşturmalıdır. Böylece, uzlaştırmaya başvurulabilmesi için de, failin suçu işlediği konusunda hukuka uygun ve muteber deliller olmalıdır. $\mathrm{Bu}$ sayede, bir kişi hakkında sadece şikâyette bulunulması suretiyle, o kişinin uzlaşmaya zorlanması ve işlemediği bir suçtan dolayı uzlaşmak zorunda bırakılması önlenmiş olur. Failin belirlenmesi ve suça ilişkin delil

\footnotetext{
${ }^{54}$ Doktrinde, failin suçu kabul etmesinin, suçu işlediğini ikrar etmesi anlamına geldiği savunulmaktadır (Yurtcan s. 646). Kanımca, uzlaştırmaya başvurulması için failin suçu tamamen ikrar etmesi yerine, suç konusu olaylardan kısmen dahi olsa sorumluluğunu kabul etmesi yeterli olmalidır.

${ }^{55}$ Committee of Experts on Mediation in Penal Matters s. 21. Aynı görüş için bkz. Kaymaz, Gökcan s. 88.

${ }^{56}$ Nurullah Kunter, Feridun Yenisey, Muhakeme Hukuku Dall Olarak Ceza Muhakemesi Hukuku, İstanbul 2002, s. 529; Doğan Soyaslan, Ceza Muhakemeleri Usulü Hukuku, Ankara 2000, s. 75.

${ }^{57}$ Ali Kemal Yıldız, Uzlaşma-Şikayet İlişkisi (Y.TCK m. 73) (Ceza Muhakemesi Hukukunda Uzlaşma, İstanbul 2005, s. 259-280) s. 278; Kaymaz, Gökcan s. 97.
} 
elde etmek için bilirkişi görüşü alınması gerekiyorsa (örneğin şüpheli veya sanığın beden muayenesi veya vücudundan örnek alınması gerekiyorsa, CMK m. 75), Cumhuriyet savcısı veya mahkeme, önce bilirkişi raporu almalı (CMK m. $63 \mathrm{vd}$ ), suçun fail tarafından işlendiği konusunda gerekli kanaate ulaştıktan sonra uzlaştırmaya başvurmalıdır.

Uzlaştırmaya başvurulabilmesi için, mağdurun gerçek kişi veya özel hukuk tüzel kişisi (örneğin bir dernek, vakıf veya ticaret şirketi) olması gerekir $^{58}$ (TCK m. 73,8). Ancak, kamu tüzel kişilerine karşı işlenen bazı suçlarda da uzlaştırmadan yararlanılabilir. Bu nedenle, yapılacak bir kanun değişikliğinde, kamu tüzel kişilerinin de belli suçlarda uzlaştırmaya başvurmasına imkân tanınmalıdır.

Mağdur, verilmiş olan zararın tümüyle veya büyük bir kısmı itibariyle giderildiğinde özgür iradesi ile uzlaşacağını bildirirse soruşturma sürdürülmez ve uzlaştırmaya başvurulur (CMK m. 253,3). Ceza muhakemesi Kanununda, mağdur-fail uzlaştırmasının temel ilkelerinden bir olan gönüllülük ilkesine bağlı kalınmıştır. Ceza uyuşmazlıklarında uzlaştırmaya başvurulabilmesi için failin ve mağdurun buna rıza göstermesi gerekir. Taraflar, uzlaştırma sırasında her zaman bu rızalarını geri alabilmelidirler ${ }^{59}$.

Failin veya mağdurun, ayırt etme gücüne sahip olmaması nedeniyle uzlaştırmanın etkilerini ve sonucunu anlayamayacak ve uzlaştırmaya sahih bir rıza gösteremeyecek olması hâlinde uzlaştırmaya başvurulmamalıdır ${ }^{60}$.

Fail ve mağdur, uzlaştırmaya başvurmaya karar vermeden önce, Cumhuriyet savcisı veya mahkeme tarafindan, sahip oldukları haklar, uzlaştırmanın işleyişi ve uzlaştırmaya başvurmanın sonuçları hakkında tam olarak bilgilendirilmelidir. Müdafi ve vekilin de faile ve mağdura uzlaştırma hakkında bilgi vermesi uygun olur. Adalet Bakanlığı, tarafları uzlaştırma konusunda bilgilendirecek rehberler hazırlamal1; bu rehberlerde, uzlaştırmaya hangi suçlarda başvurulabileceği, uzlaştırmaya başvurulmasının koşulları, uzlaştırmanın niteliği, işleyiş usulü ve uzlaştırmanın sonuçları hakkında ayrıntılı bilgi verilmelidir ${ }^{61}$.

Uzlaştırmaya kovuşturma evresinde mahkeme tarafindan başvurulabilir. Soruşturma evresinde uzlaştırmaya başvurulmak istenmemişse veya özel kanun hükümleri gereğince doğrudan kamu davası açılmışsa ya da suç, dava konusu fiilin niteliğinin değişmesi suretiyle uzlaştırma kapsamına giren bir suça dönüşmüşse mahkemece uzlaştırmaya başvurulabilir. Esasen,

\footnotetext{
58 Türk Ceza Kanununun 11. maddesinin 2. fikrasında belirtilen sutça mağdurun yabancı hükûmet olması ve şikâyette bulunması hâlinde uzlaştırmaya başvurulması mümkün değildir. Aynı şekilde, Türk Ceza Kanununun 340 ve 341. maddelerinde belirtilen suçlarda, ilgili yabancı devlet şikâyetçi olduğunda uzlaştırmaya başvurulamaz (Kaymaz, Gökcan s. 76).

${ }_{59}$ Committee of Experts on Mediation in Penal Matters s. 5.

${ }^{60}$ Committee of Experts on Mediation in Penal Matters s. 21

${ }^{61}$ Committee of Experts on Mediation in Penal Matters s. 20.
} 
kovuşturma yapılabilmesi şikâyete bağlı suçlarda, suçtan zarar görenin, hükmün kesinleşmesine kadar şikâyetinden vazgeçmesi mümkün olduğundan (TCK m. 73,4), bu aşamaya kadar uzlaştırmaya başvurulması da mümkün olmalıdır. Dolayısıyla, kanun yollarında da uzlaştırma uygulanabilir $^{62}$. Mahkeme, kamu davası açılmışsa, 253. maddede belirtilen usulü uygular. Uzlaşmanın gerçekleşmesi hâlinde davanın düşmesine karar verilir (CMK m. 254). Uzlaşmaya varılması nedeniyle fail hakkında "kovuşturmaya yer olmadığına" veya "davanın düşmesine" karar verilmesinden sonra fail, Ceza Muhakemesi Kanununun 141. maddesine dayanarak, koruma tedbirleri nedeniyle devlete karşı maddî veya manevî tazminat davası açamaz (CMK m. 144,1/c).

\section{II- Uzlaştırıcı Avukatın Atanması ve İşlevi}

Uzlaştırmaya başvurulmasına karar verilmesinden sonra, Cumhuriyet savcısı, fail ile mağdur arasında uzlaştırma işlemlerini idare etmek, tarafları bir araya getirerek onların bir anlaşmaya varmalarını sağlamak üzere bir uzlaştırıcı atanmasına karar verir ${ }^{63}$. Uzlaştırıcının atanmasında öncelikle fail ve mağdurun üzerinde anlaştığı bir avukat tercih edilir. Fail ve mağdur uzlaştırıcı seçiminde anlaşamazlara, savcı, barodan bir veya daha fazla avukatın uzlaştırıcı olarak görevlendirilmesini ister ${ }^{64}$. Uzlaştırıcı olabilmek için baro levhasına kayıtlı avukat olmak zorunludur (CMK m. 253,4). Her ne kadar mukayeseli hukukta avukat olmayan kişilerin de uzlaştırıcılık yaptığ 1 görülse de, ülkemizde bu kurumun yeni olması, kötüye kullanılmamas1, yapılabilecek hataların asgariye indirilmesi, fail ve mağdurun haklarının tam olarak korunması, uzlaştırma sürecinde ceza muhakemesi hukuku bilgisinin de gerekmesi ve gerektiğinde uzlaştırıcı avukatın hukukî ve cezaî sorumluluğunun doğacak olması gibi nedenlerle uzlaştırıcıların avukatlar arasından seçilmesi isabetli bir düzenlemedir ${ }^{65}$. Ancak, uzlaştırıcılara müzakere hünerleri ve uzlaştırma sürecinin işleyişi konusunda hem başlangıç eğitimi, hem meslek içi eğitim verilmelidir ${ }^{66}$. Uzlaştırmanın, Barolara getirdiği yükümlülüklerin yerine getirilmesinde uyulacak usullerin

\footnotetext{
${ }^{62}$ Karş. Kaymaz, Gökcan s. 120.

${ }^{63}$ Söz konusu maddenin gerekçesi şu şekildedir: "Suç faili ve mağdur arasındaki maddî ve manevî zararı giderme, bazen müzakereyi gerektirebilir. Böyle bir olasılığı karşılamak üzere dördüncü fikra Cumhuriyet savcısının uzlaşma işlemlerini idare ederek tarafları birleştirip bir sonuca ulaşmalarını sağlamak üzere bir veya birden çok uzlaştırmacı atamasını öngörmüştür. Uzlaştırmacı bir avukat olacaktır. Adı geçen derhal işe koyulacak ve atanmasından itibaren on gün içinde müdahalelerini ve sonuçlarını belirten bir raporu Cumhuriyet savcısına sunacaktır".

${ }^{64}$ Tarafların anlaşması hâlinde, soruşturmanın veya kovuşturmanın yapıldı ̆̆ı yerdeki baronun dışındaki bir baroda kayıtlı olan bir avukatın da uzlaştırıcı olarak atanması mümkündür.

${ }^{65}$ Karş. Tamer Soysal, Türk Ceza Hukukunda Uzlaşma (Ceza Muhakemesi Hukukunda Uzlaşma, İstanbul 2005, s. 203-246), s. 228.

${ }^{66}$ Committee of Experts on Mediation in Penal Matters s. 6; Kaymaz, Gökcan s. 134.
} 
gösterilmesi amacıyla, Türkiye Barolar Birliğince çıkarılan Yönergenin ${ }^{67} 7$. maddesinde, "Baroların uzlaştırıcı avukat yetiştirmek için eğitim seminerleri düzenleyecekleri ve eğitim seminerlerine katılan avukatlara görevlendirmede öncelik tanıyacakları" belirtilmiştir ${ }^{68}$.

Uzlaştırıcı olarak atanan avukat, uzlaştırıcılık görevini kabul etmek zorunda değildir. Avukatın bu görevi reddetmesi halinde bunu derhal Baroya (veya doğrudan atanmışsa taraflara) bildirmeli ve Baro tarafindan başka bir avukat atanmalıdır.

Uzlaştırıcı, atanmasının ardından uzlaştırma toplantılarını programlamalıdır ${ }^{69}$. Cumhuriyet savıcı veya mahkeme, uzlaştırma süreci başlamadan önce, dava ile ilgili olaylar hakkında uzlaştırıcıya gerekli bilgi ve belgeleri vermelidir. Uzlaştırıcının avukat olması da dikkate alındığında, uzlaştırıcının dava dosyasını inceleme ve dava dosyasından örnek alma hakk1 da vardır ${ }^{70}$ (Av.K. m.2,3; CMK m. 153; 234).

Uzlaştırıc1, uzlaştırma müzakerelerini güvenli bir ortamda gerçekleştirmelidir ${ }^{71}$. Uzlaştırma müzakerelerinin gizliliği de dikkate alındığında, müzakerelerin güvenli ve tarafsız bir ortamda yapılmasını sağlayacak alt yapıyı oluşturmanın önemi daha açık anlaşılır. Bu maksatla, Adalet Bakanlığınca adliyelerde uzlaştırma odaları oluşturulmalıdır ${ }^{72}$.

67 "Türk Ceza Kanunu 73. Maddesi ile Ceza Muhakemesi Kanunu 253, 254 ve 255 Maddelerinde Düzenlenen Uzlaşmanın Uygulanması Hakkında Yönerge", Türkiye Barolar Birliği Yönetim Kurulunun, 04-05 Eylül 2005 günlü toplantısında, 394-2 Karar numarası ile kabul edilmiştir (Bkz. http://www.barobirlik.org.tr).

${ }^{68}$ Ayrıca bkz. Türkiye Barolar Birliği Yönergesi m. 6.

69 Türkiye Barolar Birliği Yönergesinin bu hususu düzenleyen 11. maddesine göre, "uzlaştırıcı olarak atanan avukat, taraflar ve varsa vekil ve temsilcileri ile en kısa sürede temasa geçmeye çalışarak tüm taraflar için uygun bir toplantı günü belirler. Uzlaştırıcı Avukat fail tarafından yatırılmıs bulunan masraf avansını kullanarak toplantı yeri, tarihi ve saatini taraflara tebliğ eder. Taraflardan birinin herhangi bir nedenle toplantıya katılmaması halinde Uzlaştırıcı Avukat tarafından yeni bir toplantı günü belirlenerek geçerli mazereti olmaksızın katılmaması halinde uzlaşma sürecinin sona ereceğini belirtir meşruhatla katılmayan tarafa bildiriliı". Uzlaştırmanın en fazla altmış gün içinde tamamlanması gerektiği dikkate alındığında (CMK m. 253,5), adlî tebligatın yapılmasındaki gecikmeler yüzünden uzlaştırma bu süre içerisinde bitirilemeyebilir. Bu nedenle, gerekli davet ve bildirimlerin faksla veya telefonla yapılması da mümkün olmalıdır.

70 Ceza Muhakemesi Kanununda, uzlaştırıcının dosya inceleme yetkisinin açıkça düzenlenmesi yararlı olacaktır. Aynı görüş için bkz. Kaymaz, Gökcan s. 104.

${ }^{71}$ Kaymaz, Gökcan s. 105.

72 Türkiye Barolar Birliği Yönergesinin 10. maddesinde bu husus düzenlenmiştir. Bu maddede, "adliye binalarında uzlaştırma görüşmelerinin gereği gibi yapılabilmesini sağlamak amacıyla Baro Başkanlığı tarafından Cumhuriyet Savcıllğından uzlaşma odalarının tahsisinin isteneceği, bu odalarda yapılacak uzlaştırma toplantı ve görüşmelerinin gizlilik ve güvenliğinin sağlanması için Cumhuriyet Savcılıklarınca gerekli önlemleri alınacăg belirtilmiştir. Cumhuriyet Savcılığınca uzlaşmaya özel sürekli oda tahsis edilemeyen durumlarda, Cumhuriyet Savcılık birimlerinin kullanımındaki odaların uzlaşma görüşmeleri sırasında kullanılması sağlanacaktır". 
Müzakerelerin ayrı toplantılarla sürdürülmesi gerekebileceğinden, yeterli sayıda uzlaştırma odasının hazır bulundurulması zorunludur. $\mathrm{Bu}$ odalar, uzlaştırıcı listelerini tutan baroların kullanımına tahsis edilmeli ve müzakerelerin güven içinde yapılması için gerektiğinde kolluk görevlilerinin yardımı sağlanmalıdır.

Uzlaştırıcının yönetiminde gerçekleştirilecek ortak ve ayrı toplantılarda uzlaştırıcı, uyuşmazlığın çözülmesi için gerektiğinde taraflara çeşitli önerilerde bulunmalı ve tarafları anlaşmaları için teşvik etmelidir. Ancak uzlaştırıcı, tarafları belli bir çözümü kabul etmeye kesinlikle zorlayamaz ${ }^{73}$. Uzlaştırıcı olarak atanan kişi tarafsız hareket etmek zorundadir ${ }^{74}$. Zira uzlaştırıcı, taraflar arasındaki uyuşmazlığın çözümünü kolaylaştıran üçüncü bir kişi olup, ne müdafi ne de vekildir ${ }^{75}$. Taraflardan biriyle arasında kişisel ilişki olan veya uyuşmazlıkla bağlantısı olan bir kişi uzlaştırıcı olarak atanamaz ${ }^{76}$. Bu konunun Ceza Muhakemesi Kanununda açıç̧a düzenlenmesi ve Kanuna, "uzlaştırıcıların, hâkimlerin reddi sebeplerine dayanarak reddedilebileceği" ve "uzlaştırıcıların reddi hâlinde, hâkimlerin reddine ilişkin 24. madde hükmünün uygulanacağı" yönünde bir hüküm koyulması yararlı olacaktır.

Ceza Muhakemesi Kanununun 253. maddesinde fail ve mağdurun, bir uzlaştırıcı atamadan, doğrudan müzakere ederek anlaşmalarının mümkün

\footnotetext{
${ }^{73}$ Uzlaştırmanın temel ilkeleri hakkında geniş bilgi için bkz. Stephen B. Goldberg, Frank E.A. Sander, Nancy H. Rogers, Sarah Rudolph Cole, Dispute Resolution: Negotiation, Mediation, and Other Processes, New York 2003, s. 111 vd.; Kovach s. 75 vd.; Gülgün Ildır, Alternatif Uyuşmazlık Çözümü (Medenî Yargıya Alternatif Yöntemler), Ankara 2003, s. 88 vd.; Özbek, Alternatif Uyuşmazlık Çözümü s. $201 \mathrm{vd.}$

${ }^{74}$ Türkiye Barolar Birliği Yönergesinin 14. maddesinde, "Uzlaştırıcının Yükümlülükleri ve Uyması Gerekli Kurallar" başlığı altında, uzlaştırıcının tarafsızlığı düzenlemiştir. Buna göre, "Uzlaştırıcı Avukat, uzlaşma görüşmeleri süresince taraflara eşit mesafede ve saygıll davranır, arabuluculuk için güvenli ve rahat bir ortam yaratır. Uzlaştırıcı Avukat tarafların incinme ve zarar görme olasılıklarına karşı hassas olur. Tarafların da birbirlerine saygılı davranmalarına azami özen gösterir. Uzlaştırıcı Avukat bu sıfatla görev yaptığı olayla ilgili olarak daha sonra vekil veya müdafi olarak görev üstlenemez".

${ }^{75}$ Uzlaştırıcının görevinin hukukî niteliğgine ilişkin görüşler için bkz. Kaymaz, Gökcan s. 107. Uzlaştırıcının işlevi itibariyle yargı benzeri (quasi-judicial) bir görev üstlendiği söylenebilir. Ancak, mahkeme kökenli uzlaştırma yolunun dava sürecinin bir parçası olmasına rağmen, uzlaştırmanın yargısal bir kurum olduğu söylenemez.

${ }^{76}$ Committee of Experts on Mediation in Penal Matters s. 23. Türkiye Barolar Birliği Yönergesinin 15. maddesinde bu ilke düzenlenmiştir. Bu maddeye göre, "Uzlaştırıcı Avukat bağımsız olmalıdır. Uzlaştırıcı avukat bağımsızlığını veya taraflarla arasında menfaat çatışması yaratabilecek veya bu izlenimi verebilecek durumları açıklamalı, gerekirse görevi kabul etmemeli veya başladıysa bırakmalıdır. Bu durumlar, uzlaştırıcının, yakınlarının veya iş ortaklarının taraflardan biri ile herhangi bir kişisel veya iş ilişsisinin bulunması, uzlaşma görüşmelerinin sonucuna yönelik olarak doğrudan veya dolaylı herhangi maddi veya diğer menfaatinin bulunması, taraflardan biri için uzlaştırıcılık dışında herhangi bir yetkiyle görev yapması gibi durumlar sayılabilir. $\mathrm{Bu}$ ve benzeri durumların varlığı halinde, Uzlaştırıcı Avukat ancak tarafların açık rızası ile göreve devam edebilir”.
} 
olup olmadığına dair bir açıklık bulunmamaktadır. Fail ve mağdurun bizzat veya avukatları aracılığıyla gerçekleştirecekleri müzakerelerle (yani uzlaşma yoluyla) anlaşmaya varmalarına bir engel bulunmamaktadır. Örneğin küçük uyuşmazlıklarda, taraflar kendi istekleri veya avukatlarının teşvikiyle, aralarındaki uyuşmazlığı müzakere (uzlaşma) yoluyla çözmeye karar verebilirler. Bu durumda bir uzlaştırıcı atanmadan, kısa süre içinde tarafların anlaşmaya varması ve bu anlaşma sonunda mağdurun şikâyetini geri alması mümkün olabilir. Uzlaşma kültürünün zamanla gerek hukukçular arasında, gerek toplumda yerleşmesiyle, uzlaşmanın yapılması daha da kolaylaşacaktır. Yapılacak kanun değişikliğinde bu hususun açıkça düzenlenmesi yararl1 olur ${ }^{77}$.

\section{III- Mağdurun Zararının Giderilmesi}

Ceza Muhakemesi Kanununun 253. maddesinde fail ve mağdurun, suçtan ortaya çıkan maddî veya manevî zararın ödenmesi şartıyla bir anlaşmaya varabileceği belirtilse de, bu mağdura "sadece bir miktar para ödenmesi gerektiği” şeklinde anlaşılmamalıdır. Gerçekten fail, mağdura bir miktar para ödeyebileceği gibi, hayır amaçlı kuruluşlara bağış yapmak gibi diğer maddî hizmetlerde bulunarak, mağdurdan özür dileyerek, özellikle hayır amaçlı kuruluşlarda olmak üzere sosyal bir kuruluşta gönüllü çalışarak, bir kamu hizmetinin görülmesine katılarak veya topluma faydalı bir birey olmasını sağlayacak rehabilitasyon ve eğitim programlarına katılmak gibi diğer bazı yükümlülükler altına girerek de mağdurun zararını giderilebiliir ${ }^{78}$. Nitekim Ceza Muhakemesi Kanununun 253. maddesinde, "mağdurun zararının ödenmesi veya giderilmesinden" söz edilerek, bu gidermenin para ödeme dışında da olmasına imkân tanınmıştır ${ }^{79}$.

$\mathrm{Bu}$ husus, küçükler tarafından işlenen suçlarda uzlaştırmaya başvurulması hâlinde daha da önem kazanır. Çocukların işlediği suçlarda uzlaştırma, Ceza Muhakemesi Kanununun 253 ilâ 255. maddelerine göre gerçekleştirilecektir $^{80}$ (Çocuk Koruma Kanunu m. 42,1). Çocukların taraf olduğu uzlaştırmalarda, çocuğun, mağdurun zararını mutlaka bir miktar para ödeyerek gidermesi amaca uygun olmadığı gibi, çoğu zaman mümkün de değildir. Çocuklar tarafından işlenen suçlarda uzlaştırmanın, çocuğu topluma kazandırmada kullanılacak bir yol olma işlevi daha açık görülmektedir. Bu nedenle çocukların, mağdurun zararını gidermek amacıyla diğer giderim yollarını kullanmasına olanak tanınmalıdır. Ayrıca, çocukların katıldığı uzlaştırmalarda, uyuşmazlık çözüm sürecinin kendine özgü özellikleri bulunması sebebiyle, usul kurallarının Ceza Muhakemesi Kanununa atıf

\footnotetext{
${ }^{77}$ Aynı görüş için bkz. Kaymaz, Gökcan s. 101.

${ }^{78}$ Committee of Experts on Mediation in Penal Matters s. 16.

${ }^{79}$ Yurtcan s. 646.

${ }^{80}$ Bkz. yuk. §2. C
} 
yapmak yerine özel olarak düzenlemesinde yarar vardır. Nitekim, Avrupa Komisyonunun 9 Kasım 2005 tarihinde Türkiye'ye yönelik olarak açıkladığı 2005 yılı ilerleme raporunda bu husus eleştiri konusu olmuştur. Raporda, çocukların haklarının korunması açısından Çocuk Koruma Kanununun yürürlüğe girmesi olumlu bir gelişme olarak değerlendirilmiş; fakat çocuk suçlularla ilgili ceza hukuku hükümlerinin hâlâ genel ceza muhakemesi kurallarıyla aynı olması ve Kanunun özel çocuk mevzuatıyla ilgili uluslararası ilkelere uygun olmaması haklı olarak eleştirilmiştir ${ }^{81}$. Uzlaştırma hükümlerini de kuşkusuz bu eleştiri kapsamında görmek ve özel olarak düzenlemek gerekir.

\section{IV- Uzlaştırma Süresi ve Zamanaşımının Durması}

Uzlaştırıcı, başvurunun yapıldığı tarihten itibaren en geç otuz gün içinde uzlaştırmayı sonuçlandırır. Cumhuriyet savcısı, bir defaya mahsus olmak üzere bu süreyi otuz gün daha uzatabilir (CMK m. 253, 5). Bu noktada önemli olan, soruşturma veya kovuşturma evresinde otuz gün içinde uzlaştırma müzakerelerinin tamamlanmasıdır. Mağdurun zararı bu sürede giderilebileceği gibi, belli bir sürece de yayılabilir. Dolayısıyla, uzlaştırma süreci sonunda yapılan anlaşmada, mağdurun zararının tazmini veya giderilmesi için otuz günden daha uzun bir süre kararlaştırılabilir (örneğin mağdura ödenecek tazminat belli taksitlere bağlanabilir veya failin bir hayır kuruluşunda daha uzun bir süre çalışması kararlaştırılabilir). Böyle bir durumda soruşturma dosyası, mağdurun zararının uzlaşmaya uygun olarak giderilmesine kadar bekletilmeli; zarar giderildiğinde kovuşturmaya yer olmadığına karar verilmeli, zarar giderilmezse soruşturmaya devam edilmelidir $^{82}$ (CMK m. 253,8).

Aynı sorun kovuşturma evresinde de ortaya çıkabilir. Kovuşturma evresinde uzlaştırmaya başvurulmuş ve uzlaşma gerçekleşmişse davanın düşmesine karar verilir (CMK m. 253,2). Kanunun öngördüğü otuz (veya süre uzatılmışsa altmış) günlük süre içinde uzlaştırma tamamlanabilir, fakat zararın giderilmesi daha uzun bir süre alabilir. Fail, mağdurun zararını gidermezse, ceza davası düşmüş olacağından, mağdurun anlaşmanın yerine getirilmesi için hukuk mahkemesinde dava açması veya cebrî icra yoluna başvurması gerekir. Bu aşamada artık bir hukuk uyuşmazlığının varlığından söz edilecektir. Uzlaştırma sonunda yapılan anlaşmanın cebrî icra yoluyla icra edilebilecek bir edim (örneğin bir para borcu, taşınır teslimi, bir işin yapılması veya yapılmaması borcu gibi) içermesi hâlinde, tutanağın kanunen ilâmlı icraya dayanak olacak belgelerden sayılması, hem uzlaşma tutanağının etkisini artıracak, hem de mağdurun hakkını daha kolay elde etmesini

${ }^{81}$ European Commission, Turkey 2005 Progress Report, COM (2005) 561 final, Brussels, 9 November 2005, SEC (2005) 1426, s. 33.

${ }^{82}$ Kaymaz, Gökcan s. 88. 
sağlayacaktır. Buna karşılık, Ceza Muhakemesi Kanununun 254. maddesinin daha farklı yorumlanarak bu sakıncanın giderilmesi mümkündür. Kanunun 254. maddesine göre, "kamu davasının açılması hâlinde, uzlaşmaya tâbi bir suç söz konusu ise, uzlaştırma işlemleri 253 üncü maddede belirtilen usule göre, mahkeme tarafindan da yapılır". Bu hükümde öngörülen atıf gereğince, 253. maddenin 8. fikrasının aynen uygulanması ve mahkemenin, ancak "zarar uzlaşmaya uygun olarak giderildiğinde ve uzlaştırma işleminin giderleri fail tarafından ödendiğinde" davanın düşmesine karar vereceği de savunulabilir. $\mathrm{Bu}$ yorum sayesinde fail, mağdurun zararını uzlaşmaya uygun olarak gidermeden davanın düşmesine karar verilmeyeceği için, mağdurun zararının giderilmemesi yüzünden ortaya çıkabilecek sorunlar büyük ölçüde önlenmiş olur. Yapılacak bir kanun değişikliğinde, getirilecek açı hükümlerle bu tereddütler giderilmelidir.

Uzlaştırma sonunda yapılan anlaşmanın yerine getirilmesini sağlamak ve aynı zamanda soruşturma veya kovuşturmanın sürüncemede kalmasını önlemek bakımından, kanunda mağdurun zararının giderilmesi için makul bir süre öngörülebilir ve bundan sonra mahkemenin kovuşturmaya yer olmadığına veya davanın düşmesine karar vermesi mümkün kılınabilili ${ }^{83}$.

Uzlaştırma süresince zamanaşımı durur (CMK m. 253,5). Kanunda zamanaşımının durduğu süreç tanımlanmamıştır. Kanununda "uzlaştırma süresi" ile kastedilen, 253. madenin 5. fikrasındaki otuz (veya süre uzatılmışsa altmış) günlük müzakere süresidir. Uzlaştırma sonunda mağdurun zararının giderilmesi için müzakere süresinden uzun bir süre kararlaştırılmışsa, zamanaşımının bu sürede de durduğunun kabulü amaca uygun olur ${ }^{84}$. Bu konudaki tereddüdün aşılması için, yapılacak bir kanun değişikliğiyle zamanaşımının durduğu sürenin açıkça belirtilmesi gerekir. Kanımca, "taraflarca uzlaştırmaya başvurulmasına karar verildiği tarihte" zamanaşımı süresi durmalıdır. Uzlaştırma süreci sonunda anlaşmaya varılmışsa, bu "anlaşma gereğince mağdurun zararının giderildiği"; anlaşmaya varılamamışsa, "taraflardan birinin veya uzlaştırıcının, uzlaştırmanın bitirildiğini bildirdiği veya uzlaştırmadan çekildiği" tarihten itibaren zamanaşımı süresi işlemeye devam etmelidir.

Ceza Muhakemesi Kanununun 235. maddesinde, ceza muhakemesinin makul bir süre içinde tamamlanması için uzlaștırma usulü belli bir süreyle sınırlandırılmıştır ${ }^{85}$. Ayrıca, uzlaştırmaya soruşturma evresinde başvurulmuş olması hâlinde, suça ilişkin dava zamanaşımının durması öngörülerek, uzlaştırma esnasında zamanaşımının dolması tehlikesi giderilmiş ve bu endişeyle uzlaştırmaya başvurulmaması önlenmiştir. Bu hükümle, Ceza Kanununun 67. maddesindeki dava zamanaşımını durduran nedenlere bir yenisi daha eklenmiştir.

${ }^{83}$ Kaymaz, Gökcan s. 108.

${ }^{84}$ Kaymaz, Gökcan s. 117.

${ }^{85}$ Committee of Experts on Mediation in Penal Matters s. 21. 


\section{V- Uzlaştırma Müzakerelerinin Gizliliği}

Uzlaşma müzakereleri gizli olarak yürütülür. Uzlaştırma sırasında ileri sürülen bilgi ve belgeler, yapılan açıklamalar, taraflarca izin verilmedikçe daha sonra açıklanamaz. Uzlaştırmanın başarısız olması nedeniyle daha sonra dava açılması hâlinde, uzlaștırma sırasında failin bazı olayları veya suçu ikrar etmiş olması davada aleyhine delil olarak kullanılamaz (CMK 253,6). Bu hüküm, uzlaştırmanın en önemli özelliklerinden bir olan gizlilik ilkesini düzenlemektedir ${ }^{86}$. Ceza uyuşmazlıklarında uzlaştırma, hem tarafların düşüncelerini özgürce açıklayabilmesini sağlamak ve bu sayede bir anlaşmaya varmalarını kolaylaştırmak, hem de tarafların menfaatlerini korumak amacıyla gizli yürütülmelidir ${ }^{87}$. Gizlilik ilkesi nedeniyle, taraflarca aksi kararlaştırılmadıkça, uzlaştırma müzakerelerinde yapılan açıklamalar daha sonra açıklanamaz. Fail, uzlaştırma müzakereleri sırasında bazı maddî olayları ve hatta suçu kabul etse bile, bu beyanlar daha sonra dava aşamasında failin aleyhine kullanılamaz ${ }^{88}$. Müzakereler sırasında tutulan kayıt ve tutanaklar, uzlaştırmanın tamamlanmasından sonra imha edilmeli, soruşturma veya dava dosyasına koyulmamalı ya da arşivlenmemelidir ${ }^{89}$. Gizlilik, ceza muhakemesinde yargılamanın alenî yapılması ilkesiyle çatıșır ve uzlaştırmanın özel niteliğini vurgular ${ }^{90}$.

\section{VI- Uzlaştırma Sürecinin Tamamlanması}

Uzlaştırma sonunda yapılan anlaşmanın geçerli olabilmesi için gönüllü, makul ve orantılı (ölçülü) olması gerekir. Buna göre, tarafların anlaşmayı kabul etmesi tamamen gönüllü olmalı ve bu anlaşmada faile yüklenen külfet ile failin işlemiş olduğu suçun ağırlığı arasında bir uygunluk ve orantı olmalıdır $^{91}$. Her ne kadar orantılllık ilkesi Ceza Muhakemesi Kanununun 253. maddesinde açıkça belirtilmese de, ceza hukukunun temel ilkelerinden olan bu ilke uzlaștırmada da aynen geçerlidir. Nitekim Türk Ceza Kanununun 3. maddesinin 1. fikrasında, "suçu işleyen kişi hakkında işlenen fiilin ağırlığıyla orantılı ceza ve güvenlilik tedbirine hükmolunur" denilmek suretiyle, "suç işleyen kimseye uygulanacak ceza hukuku yaptırımlarının haklı ve ölçülü olması gerektiğine" işaret edilmiştir. "Ancak haklı ve suçun ağırlığıyla orantılı bir yaptırım ile suç işleyen kişinin bu fiilinden pişmanlık duyması sağlanabilir ve yeniden topluma kazandırılması söz konusu

${ }^{86}$ Gizlilik hakkında bkz. Özbek, Alternatif Uyuşmazlık Çözümü s. 213; Kovach s. 262; Kaymaz, Gökcan s. 109.

${ }^{87}$ Uzlaşma müzakerelerin gizliliği ve sonradan delil olarak kullanamaması, Türkiye Barolar Birliği Yönergesinin 12. maddesinde düzenlenmiş ve uzlaşma toplantılarına taraflar, kanuni temsilcileri, müdafi, vekil ve uzlaştırıcı dışında kimsenin katılamayacağı öngörülmüştür.

${ }^{88}$ Committee of Experts on Mediation in Penal Matters s. 21.

${ }^{89}$ Aynı görüș için bkz. Kaymaz, Gökcan s. 121.

${ }^{90}$ Committee of Experts on Mediation in Penal Matters s. 17

${ }^{91}$ Committee of Experts on Mediation in Penal Matters s. 24; Kaymaz, Gökcan s. 106. 
olabilir"92. Bu nedenle, uzlaştırma sonunda yapılan anlaşma faile makul bir yükümlülük yüklemeli ve örneğin, üzerinde anlaşmaya varılan tazminat miktarı, işlenen suçun ağırlığına oranla aşırı yüksek olmamalıdır.

Uzlaştırıcı, yaptı̆̆ işlemleri ve uzlaşmayı sağlayıcı müdahalelerini belirten bir raporu on gün içinde ilgili Cumhuriyet savcısına sunar (CMK m. 253,7). Uzlaştırma tamamlandıktan sonra uzlaştırıcı, uzlaştırma sürecinde yapılan işlemleri ve uzlaştırmanın sonucunu belirten yazılı bir rapor sunmalıdır. Uzlaştırma sonunda taraflar anlaşmaya varırsa, uzlaşma konusunu, yerini, tarihini, karşılıklı yerine getirilmesi gereken hususları içeren bir tutanak düzenlemeli ve fail, mağdur, varsa avukatları ve uzlaştırıcı tarafından imzalanmalıdır ${ }^{93}$. Uzlaştırmanın başarısız olması hâlinde, bunun nedenleri raporda kısaca belirtilmelidir. Ancak gizlilik ilkesi gereği, tutanakta veya uzlaştırıcının raporunda, müzakerelerin içeriği, müzakerelerde yapılan beyan ve açıklamalar ve tarafların davranışları hakkında kesinlikle bilgi verilmemelidir ${ }^{94}$. Bu raporun, Adalet Bakanlığı veya Türkiye Barolar Birliği tarafından hazırlanan bir örnek esas alınarak, mümkün olduğunca yeknesak biçimde düzenlenmesi uygun olur. Cumhuriyet savcisı, kendisine sunulan bu raporu, gerekli unsurların bulunup bulunmadığ 1 hususunda incelemelidir.

Zarar uzlaşmaya uygun olarak giderildiğinde ve uzlaştırma işleminin giderleri fail tarafından ödendiğinde, kovuşturmaya yer olmadığına karar verilir (CMK m. 253,8). Cumhuriyet savcisı buna karar vermeden önce, uzlaştırma sürecinin usulüne uygun gerçekleştiğinden emin olmalıdır. Uzlaştırma sürecinde tarafların iradesi cebir veya tehdit ile sakatlanmışsa, taraflar özgür iradeleriyle hareket edememişse veya zarar uzlaşmaya uygun olarak giderilmemişse kovuşturmaya yer olmadığı kararı verilmemeli ve kamu davası açılmalıdır. Cumhuriyet savcısı bu hususlarla sınırlı olarak uzlaşma sürecini denetlemelidir ${ }^{95}$.

Uzlaştırıcıya ödenecek ücret uzlaştırma işlemi giderlerinden olup fail tarafından karşılanmalıdır. Bu ücret, avukatlık ücret tarifesinde ${ }^{96}$ ayrıca gösteriliri $^{97}$ (Ceza Muhakemesi Kanununun Yürürlük ve Uygulama Şekli Hakkında Kanun m. 13, 4). Fail adlî yardımdan yararlanıyorsa uzlaştırma

92 Bkz. 3. maddenin gerekçesi (T.C. Adalet Bakanlığı Yayın İşleri Dairesi Başkanlığı, Türk Ceza Kanunu, Ankara 2004, s. 160).

${ }^{93}$ Uzlaştırma sürecine savcı veya hâkim katılmadığı için, bu tutanakta onların imzasının bulunması gerekmez. Ayrıca bkz. Türkiye Barolar Birliği Yönergesi m. 13.

${ }^{94}$ Committee of Experts on Mediation in Penal Matters s. 25.

${ }^{95}$ Kaymaz, Gökcan s. 91.

${ }^{96}$ Bkz. 5271 Sayılı Ceza Muhakemesi Kanunu Gereğince Yapılacak Hukuki Yardımlar İçin 5320 Sayılı Ceza Muhakemesi Kanununun Yürürlük ve Uygulama Hakkında Kanunun 13'üncü Maddesi Uyarınca Hazırlanan Avukatlık Ücret Tarifesi (RG 01.06.2005, Sa. 25832). Uzlaştırıcılık ücretinin takdirinde, hukukî yardımın bittiği tarihte yürürlükte olan tarife esas alınır (Tarife m. 6).

${ }^{97}$ RG 31.03.2005, Sa. 25772 (Mükerrer). 
giderlerini ödememelidir. Uzlaştırma süreci sonunda uzlaşmaya varılırsa, fail uzlaştırma giderleri kapsamında olan uzlaştırıcının ücretini de ödeyecektir. Ancak, uzlaşmaya varılamaması durumunda uzlaştırıcının ücretinin kim tarafindan ödeneceği kanunda belli değildir. Ceza Muhakemesi Kanununda yapılacak düzenlemeyle bu konudaki boşluk doldurulmalıdır. Bu boşluk, tarafların uzlaştırmaya başvurmaya karar vermesi hâlinde, uzlaştırıcının ücretinin fail tarafindan peşin olarak yatırılması suretiyle giderilebilìr ${ }^{98}$.

Uzlaştırma sonunda anlaşmaya varılması ve bu anlaşmanın yerine getirilmesi nedeniyle kovuşturmaya yer olmadığına veya davanın düşmesine karar verilmesi hâlinde, uzlaşma konusu olan aynı olaylar nedeniyle, aynı taraflar arasında, aynı konuda yeni bir ceza davası açılamamalıdır. Aksi hâlde, bir kimseye bir eylemden dolayı birden fazla ceza verilemeyeceği (ne bis in idem) kuralı $^{99}$ ihlâl edilmiş olur ${ }^{100}$. Aynı şekilde, uzlaşmaya varılmasından ve yapılan anlaşmaya uygun olarak mağdurun zararının giderilmesinden sonra hukuk mahkemesinde de şahsi hak davası açılamamalıdır ${ }^{101}$. Böyle bir davanın açılması hâlinde, davanın hukukî yarar yokluğundan reddi gerekir.

Uzlaştırmaya başvurulması ve kovuşturmama veya davanın düşmesi kararı verilmesinden sonra, suçun ağırlaşması (örneğin mağdurun ölümü nedeniyle neticenin değişmesi) ve takibi şikâyete bağlı olmaktan çıkması hâlinde, uzlaşmaya rağmen kamu davası açılabilir.

Aralarında iştirak ilişkisi olsun veya olmasın birden çok kişi tarafindan işlenen suçlarda, ancak uzlaşan kişi uzlaşmadan yararlanır (CMK m. 255).

\section{VII- Uzlaştırma Sonunda Başvurulabilecek Kanun Yolları}

Uzlaştırma sonunda verilecek kararlara karşı hangi kanun yoluna başvurulabileceği Ceza Muhakemesi Kanununda düzenlenmemiştir. $\mathrm{Bu}$

\footnotetext{
98 Nitekim Türkiye Barolar Birliği Yönergesinin 9. maddesinde bu husus şu şekilde düzenlenmiştir: "Uzlaşma toplantılarına davet, toplantıların yapılacağı Cumhuriyet Savcılıklarınca tahsis edilen mekânın masrafları ve diğer giderler için makul bir masraf avansı da Baro ilgili birimi tarafından tespit edilir. Uzlaştırıcı avukat ancak yukarıda belirtilen ücret ve masraf avansının fail tarafından Baro adına bu amaçla özel olarak açılan banka hesabına depo edilmesi ile göreve başlar. Uzlaştırıcı avukat uzlaşma toplantıları sonucunda CMK 253/7 uyarınca düzenlediği nihai raporun bir örneğini Baro ilgili birimine sunduğunda ücrete hak kazanır ve Baro hesabında depo edilmiş olan ücret kendisine derhal ödenir. Uzlaşma görüşmelerinin sona ermesinden sonra varsa artan avansın yatırana iadesine Baro karar verir". ${ }_{99} \mathrm{Bu}$ kural, ceza muhakemesi hukukunun temel ilkelerinden olup, Ceza Muhakemesi Kanununun 223. maddesinin 7. fikrasında da düzenlenmiş̧tir. Bu kuralın tanımı için bkz. Kunter, Yenisey s. 32.

${ }^{100}$ Committee of Experts on Mediation in Penal Matters s. 21.

101 Kaymaz, Gökcan s. 116. Ayrıca bkz. yuk. § 2, C'de zikredilen Yargitay Ceza Genel Kurulu kararı.
} 
durumda, Ceza Muhakemesi Kanununun, olağan kanun yollarını düzenleyen 267 ve devamındaki maddeleri uygulanmalıdır ${ }^{102}$. Buna göre, soruşturma evresinde, uzlaştırma sonunda savcının verdiği kovuşturmama kararına itiraz edilebilir (CMK m.172 vd.). Aynı şekilde, kovuşturma evresinde uzlaştırmaya başvurulduğunda verilen davanın düşmesi kararına karşı istinaf yoluna gidilebilir (CMK m. 272). Davanın düşmesine ilişkin ilk derece mahkemesi kararları ile ilgili olarak bölge adliye mahkemesince verilen davanın düşmesi veya istinaf başvurusunun reddine dair kararlar temyiz edilemez $^{103}$ (CMK m. 286,2/g).

\section{B) Şikâyetin Geri Alınması ve Uzlaştırma}

Türk Ceza Kanununun 73. maddesine göre, kovuşturması şikâyete bağlı suçlarda suçtan zarar gören kişinin vazgeçmesi davayı düşürür (TCK m. 73,4). Ceza hukukumuzda şikâyetten vazgeçmenin mümkün olması karşısında, uzlaştırmanın beklenen işlevi yerine getirip getirmeyeceği sorusu akla gelebilir ${ }^{104}$. Şikâyetten vazgeçme uzlaştırmaya nazaran daha kolay bir yol olsa da, uzlaștırmanın ișlevini ortadan kaldırmamaktadır. Herșeyden önce, mağdurun şikâyette bulunduktan sonra, faille arasındaki anlaşmazlıkları kendiliğinden çözmesi, tarafların uzlaştırıcının yardımı olmadan doğrudan uzlaşması hiç de kolay değildir. Müzakere hünerlerini kullanan, mekik diplomasisi ve benzeri yollarla gerçekleştireceği ortak ve özel oturumlarda tarafları adım adım anlaşmaya yaklaştıran, tarafların her ikisinin de tatmin olacağ 1 çözüm seçeneklerinin bulunmasına yardımcı olan hünerli bir uzlaştırıcının tarafları anlaştırmadaki katkısı küçümsenemez. Uzlaştırmanın kapsamının zamanla gelişebileceği ve takibi şikâyete bağlı olmayan suçların da uzlaştırma kapsamına alınabileceği düşünüldüğünde, uzlaştırmanın işlevi daha açık görülür ${ }^{105}$. Ayrıca, uzlaştırma sonunda mağdurun hukuk mahkemesinde dava açması mümkün değilken, mağdurun şikâyetten vazgeçtiği sırada şahsi haklarından da vazgeçtiğini ayrıca açıklamaması hâlinde hukuk mahkemesinde dava açması mümkündür ${ }^{106}$ (TCK m. 73,7). Bu hâlde uyuşmazlık tam olarak bitmeyecek ve özel hukuk alanında devam edecektir. Oysa uzlaştırma ile uyuşmazlığın her yönüyle tamamen bitirilmesi amaçlanır. Bu nedenlerle, toplumsal barışa daha fazla hizmet edecek olan uzlaştırma kuşkusuz failin daha lehinedir.

\footnotetext{
${ }^{102}$ Yurtcan s. 647.

${ }^{103}$ Kaymaz, Gökcan s. 119.

${ }^{104} \mathrm{Bu}$ konuda bilgi için bkz. Yıldız s. 275 vd.

${ }^{105}$ Yildiz s. 276.

${ }^{106}$ Bu konuda bilgi için bkz. Kunter, Yenisey s. 82; Kaymaz, Gökcan s. 84.
} 


\section{Sonuc}

Ceza Muhakemesi Hukukumuzda uzlaştırmanın düzenlenmesi olumlu bir gelişmedir. Ceza Muhakemesi Kanununda ağılık soruşturma evresindedir ve amaç, davanın bir duruşmada sonuçlanmasını sağlayacak hazırlığın yapılmasıdır. Bu amaca ulaşılabilmesi için uzlaştırma yolunun etkin bir şekilde işletilmesi çok önemlidir.

Uygulamada uzlaştırma henüz yeterince işletilememektedir. Bunun iki temel nedeni bulunmaktadır. Birinci neden, kanundaki düzenlemelerin yetersiz olmasidır. Ceza Muhakemesi Kanununun ve Türk Ceza Kanununun uzlaştırmaya ilişkin maddeleri yeniden gözden geçirilerek, uzlaştırmaya tâbi suçlar tekrar belirlenmeli ve yapılacak bir değișiklikle, uzlaștırmaya ilișkin kanun maddelerindeki eksiklikler tamamlanmalıdır. Böylece, uygulamada karşılaşılan birçok sorun ve belirsizlik ortadan kaldırılmış olur. Ayrıca, hazırlanacak bir uzlaştırma yönetmeliği de, uzlaştırmanın işleyişi konusunda ortaya çıkan belirsizliklerin giderilmesine katkıda bulunacaktır.

Uzlaştırmanın işleyişindeki aksaklıkların ikinci nedeni, uzlaştırmanın uygulamada yeterince bilinmemesi ve eğitim eksikliğidir. Uzlaştırmanın başarılı olabilmesi için, savcıların, hâkimlerin, uzlaştırıcı avukatların ve toplumun eğitimine büyük önem verilmelidir. Yapılacak meslek içi eğitimlerde uzlaştırma eğitimine ağırlık verilmelidir. Fail ve mağdura, uzlaştırmaya başvurmayı isteyip istemedikleri sorulmadan önce, uzlaştırmanın ne olduğu, faydaları, amaçları, sunduğu güvenceler ve sonuçları hakkında detaylı bilgi verilmelidir. $\mathrm{Bu}$ maksatla taraflar, kendilerine uzlaştırma önerilmeden önce, eğitimli bir uzlaştırıcı avukatın huzurunda bir bilgilendirme toplantısına katılmalıdırlar. Ayrıca, uzlaştırma hakkında bilgi veren kitapçık, afiş ve posterler bastırılarak adliyelerde, karakollarda ve hatta kamuya açık yerlerde dağıtılmalı, bu suretle toplum aydınlatılmalıdır. Yazılı ve görsel medyada, özellikle televizyonda ve internette, uzlaştırma konusunda halkı bilgilendirecek eğitim programları yayınlanmalıdır. Kişilerin, uzlaştırmanın ne olduğunu bilmeden uzlaştırmaya başvurmayı kabul etmesi beklenemez. Kanunlarla getirilen yeni kurumların ülkemizde yerleşmesi için gerekli alt yap1 oluşturulmalıdır. Bu tür kurumların mukayeseli hukuktaki başarısı, kuşkusuz eğitime verilen önemden kaynaklanmaktadır.

$\mathrm{Bu}$ çalışmalara ilave olarak, uzlaştırıcı avukatlara yönelik etik kurallar (meslek kuralları) oluşturulmalı ve bu kurallara uyulmasına azami özen gösterilmelidir. Önümüzdeki yıllarda uzlaştırmanın özel hukuk ve idare hukukunda da gelişeceği, mahkeme kökenli uzlaştırmanın uygulamaya gireceği ve aynı uzlaştırıcı avukatların bu alanlarda da çalışacağı dikkate alındığında, söz konusu etik kuralların genel bir uygulama kazanması ve bunun için de avukatlık meslek kurallarına dâhil edilmesi gerektiği kolayca anlaş1lır. Barolar Bünyesinde kurulacak uyuşmazlık çözüm merkezleri, uzlaştırma ve diğer alternatif uyuşmazlık çözüm yollarının yaygınlaştırılması ve hukukçulara öğretilmesi için gerekli çalışmaları yapmalıdır. 